This item is the archived peer-reviewed author-version of:

Facile synthesis of $B a_{1-x} K_{x} F e_{2} A s_{2}$ superconductors via hydride route

\title{
Reference:
}

Zaikina Julia V., Batuk Maria, Abakumov Artem M., Navrotsky Alexandra, Kauziarich Susan M..- Facile synthesis of $B a_{1-x} K_{x} F e_{2} A s_{2}$ superconductors via hydride route Journal of the American Chemical Society / American Chemical Society - ISSN 0002-7863 - 136:48(2014), p. 16932-16939 Full text (Publishers DOI): http://dx.doi.org/doi:10.1021/ja509907r

Handle/Permalink: http://hdl.handle.net/10067/1213310151162165141 


\title{
Article
}

\section{Facile Synthesis of BaKFeAs Superconductors via Hydride Route}

\author{
Julia V. Zaikina, Maria Batuk, Artem Abakumov, Alexandra Navrotsky, and Susan M. Kauzlarich
}

J. Am. Chem. Soc., Just Accepted Manuscript • DOI: 10.1021/ja509907r • Publication Date (Web): 11 Nov 2014

Downloaded from http://pubs.acs.org on November 16, 2014

\section{Just Accepted}

"Just Accepted" manuscripts have been peer-reviewed and accepted for publication. They are posted online prior to technical editing, formatting for publication and author proofing. The American Chemical Society provides "Just Accepted" as a free service to the research community to expedite the dissemination of scientific material as soon as possible after acceptance. "Just Accepted" manuscripts appear in full in PDF format accompanied by an HTML abstract. "Just Accepted" manuscripts have been fully peer reviewed, but should not be considered the official version of record. They are accessible to all readers and citable by the Digital Object Identifier (DOI®). "Just Accepted" is an optional service offered to authors. Therefore, the "Just Accepted" Web site may not include all articles that will be published in the journal. After a manuscript is technically edited and formatted, it will be removed from the "Just Accepted" Web site and published as an ASAP article. Note that technical editing may introduce minor changes to the manuscript text and/or graphics which could affect content, and all legal disclaimers and ethical guidelines that apply to the journal pertain. ACS cannot be held responsible for errors or consequences arising from the use of information contained in these "Just Accepted" manuscripts. 
Introduction. Interest in iron arsenide superconductors has been growing ${ }^{1}$ since the discovery of superconductivity at 26 $\mathrm{K}$ in the oxopnictide $\mathrm{LaFeAsO}_{1-\mathrm{x}} \mathrm{F}_{\mathrm{x}}{ }^{2}$ in 2008. Subsequently other parent compounds have been identified, including $\mathrm{AFe}_{2} \mathrm{As}_{2}(\mathrm{~A}=\mathrm{Ca}, \mathrm{Ba}, \mathrm{Sr}, \mathrm{Eu}), \mathrm{AFeAs}(\mathrm{A}=\mathrm{Li}$ or $\mathrm{Na}), \mathrm{FeE}(\mathrm{E}=$ $\mathrm{Se}$ or $\mathrm{Se} / \mathrm{S} / \mathrm{Te}$ ), where doping or application of external pressure induces superconductivity. ${ }^{3}$ Superconductivity in the $\mathrm{BaFe}_{2} \mathrm{As}_{2}{ }^{4}$ parent compound (Figure 1) can be realized either by hole doping through partial substitution of $\mathrm{Ba}^{2+}$ by $\mathrm{Na}^{+}, \mathrm{K}^{+}$ or $\mathrm{Rb}^{+5,6,7,8}$ or by electron doping via partial substitution of $\mathrm{Fe}$ by $\mathrm{Co}$ or $\mathrm{Ni}^{9}$ or even by isovalent substitutions of As by P. ${ }^{10}$ The most studied and well characterized system is the superconducting solid solution $\mathrm{Ba}_{1-\mathrm{x}} \mathrm{K}_{\mathrm{x}} \mathrm{Fe}_{2} \mathrm{As}_{2}$, where a maximum $T_{\mathrm{c}}$ of $38 \mathrm{~K}$ is observed for $x$ close to 0.4.

Compared to cuprates, Fe-based superconductors have several advantages for practical applications, ${ }^{12-14}$ such as low anisotropy and large upper critical field $\mathrm{H}_{\mathrm{c} 2}$ up to $250 \mathrm{~T}$. Since their critical temperature $T_{\mathrm{c}}$ is higher than that of niobium-based superconductors, Fe-based superconductors are an attractive replacement for magnet applications at $20-50 \mathrm{~K}$ temperature range.$^{14}$ For practical applications such as magnets and cables, the powder-in-tube (PIT) technique has been suggested, ${ }^{14}$ which includes packing of the corresponding powdered materials into a metal tube, which is further swaged and drawn to wire with a heat treatment if necessary. The method proposed to fabricate iron-based superconducting wires via the PIT technique can be realized in situ or ex situ. For in situ PIT, the mixture of starting materials is packed into a metal tube and the annealing is performed after wire shaping, while in the $e x$ situ PIT method, the pre-synthesized superconducting materi- als are packed into metal tubes. ${ }^{14}$ While convenience of the in situ PIT method is evident, the wires obtained by heat treatment of the elements have low critical current density due to the current blocking associated with cracks, porosity, grain boundary wetting by secondary phases, and phase inhomogeneities. ${ }^{13,14}$ Slow kinetics of the processes associated with the preparation of $\mathrm{K}$-doped $\mathrm{BaFe}_{2} \mathrm{As}_{2}$ and related compounds by heat treatment of the elements is a reason for the observed poor material behavior. The presence of secondary current blocking phases as well as oxygen-rich amorphous layers may alter the intergranular connectivity, and thus impair material performance. ${ }^{14}$ Therefore, a fast route which gives access to fine and homogeneous powders of doped $\mathrm{BaFe}_{2} \mathrm{As}_{2}$ superconductors is highly desirable.

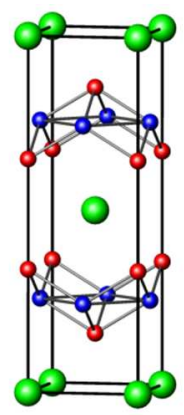

Figure 1. Crystal structure of $\mathrm{BaFe}_{2} \mathrm{As}_{2}$. Ba: green, Fe: blue, As: red. 
Despite very active research in the field of iron arsenide superconductors, the synthesis of the $\mathrm{K}$-doped $\mathrm{BaFe}_{2} \mathrm{As}_{2}$ still remains a challenge. The associated synthetic difficulties include high vapor pressure and toxicity of arsenic, high moisture/oxygen affinity, and low melting points and volatility of potassium and barium. The solid state method used for the preparation of $\mathrm{K}$-doped $\mathrm{BaFe}_{2} \mathrm{As}_{2}$ from the elements includes several annealing steps with intermediate regrinding and pressing of the pellets needed to improve homogeneity of the products and facilitate diffusion of the components. ${ }^{11,15} \mathrm{An}$ other suggested method for the preparation of the bulk microcrystalline $\mathrm{K}$-doped $\mathrm{BaFe}_{2} \mathrm{As}_{2}$ includes reaction of the presynthesized precursors, such as $\mathrm{BaAs}, \mathrm{K}_{3} \mathrm{As}$ and $\mathrm{Fe}_{2} \mathrm{As}$ at 1323 K. ${ }^{16}$

We have developed a new synthesis method utilizing potassium and barium hydrides as reactive precursors to prepare $\mathrm{K}$ doped $\mathrm{BaFe}_{2} \mathrm{As}_{2}$. The hydride route to non-oxide materials has been explored for Zintl phases, such as $\mathrm{Na}_{4} \mathrm{Si}_{4}, \mathrm{Na}_{4} \mathrm{Ge}_{4}, \mathrm{~K}_{4} \mathrm{Ge}_{4}$, $\mathrm{Mg}_{2} \mathrm{Si}^{17}{ }^{18}$ Synthesis from hydrides provides better mixing and easy handling of the starting materials (unlike elemental $\mathrm{K}$ and $\mathrm{Ba}$, corresponding hydrides are salt-like powders), consequently leading to lower synthesis temperatures and/or faster reactions. Another important feature of the hydride route is the reducing atmosphere provided by the evolved hydrogen, thus facilitating preparation of oxygen-free powders. The hydride route is also expected to facilitate sintering and preparation of dense samples, since the powders feature clean, oxygen-free surfaces. Several experimental parameters can be varied to optimize synthesis conditions, e.g. stoichiometry, temperature, time, and ball milling vs. hand grinding. ${ }^{17}$ We show by synchrotron X-ray powder diffraction, magnetometry, and transmission electron microscopy that the samples of $\mathrm{Ba}_{1}$ ${ }_{x} \mathrm{~K}_{\mathrm{x}} \mathrm{Fe}_{2} \mathrm{As}_{2}$ prepared by the new hydride route exhibit identical structural parameters and similar dependence of $T_{\mathrm{c}}$ upon the $\mathrm{K}$ content as samples prepared by the traditional solid state method.

\section{Experimental Section}

Chemicals. Barium hydride powder $\left(\mathrm{BaH}_{2}\right.$, Materion Advanced Chemicals, $95 \%$ ), iron powder (Fe, Puratronic, 99.999 $\%$, 22 mesh), and arsenic pieces (As, Johnson Matthey, $99.9999 \%$ ) were used as received. Potassium hydride (KH, 30 wt\% dispersion in mineral oil, Sigma-Aldrich) was washed with hexane several times and dried in vacuum before use. All manipulations were carried out in a glove box under dry argon atmosphere. Iron arsenide FeAs precursor was synthesized by reaction of stoichiometric mixtures of iron powder and arsenic powder prepared from pieces by grinding in an agate mortar. A silica glass ampoule with iron and arsenic mixtures in 1:1 molar ratio were sealed under vacuum and slowly heated to $873 \mathrm{~K}$ in $10 \mathrm{~h}$ and annealed at this temperature for $24 \mathrm{~h}$, then heated to $1273 \mathrm{~K}$ in $12 \mathrm{~h}$ and annealed at this temperature for $24 \mathrm{~h}$ and furnace cooled. According to powder X-ray diffraction, the FeAs precursor contains up to $6 \mathrm{wt} . \%$ of $\mathrm{FeAs}_{2}$ impurity.

CAUTION. Barium hydride and potassium hydride powders are reactive to oxygen and moisture and must be handled under an inert atmosphere with care.

Sample Preparation. Samples of $\mathrm{Ba}_{1-\mathrm{x}} \mathrm{K}_{\mathrm{x}} \mathrm{Fe}_{2} \mathrm{As}_{2}(0 \leq \mathrm{x} \leq 1)$ were prepared according to the following general procedure, which includes ball milling of $\mathrm{BaH}_{2}$ and/or $\mathrm{KH}$ hydrides together with pre-made $\mathrm{FeAs}$ precursor or elemental $\mathrm{Fe}$ and $\mathrm{As}$ in the different stoichiometric ratios following by annealing at three different temperatures for $48 \mathrm{~h}$ in sealed $\mathrm{Nb}$ containers. A high-energy Spex $8000 \mathrm{M}$ mill with a tungsten carbide lined grinding vial set (volume $5 \mathrm{ml}$ ) and one tungsten carbide ball (diameter $1.12 \mathrm{~cm}$ ) was used to ball mill mixtures of $\mathrm{BaH}_{2}$ and/or $\mathrm{KH}$ with FeAs precursor or with elemental Fe and As in a desired molar ratio with a total mass of $0.5 \mathrm{~g}$. The milling vial was additionally sealed in a metal-coated plastic bag in a glove box under argon atmosphere to prevent oxidation of the components during ball milling. The reagents were intimately mixed in the mill for $30 \mathrm{~min}$, and the milling vial was returned to the glove box for further manipulation. The ball milled powders (total mass $\sim 0.5 \mathrm{~g}$ ) were loaded into $\mathrm{Nb}$ containers (typical size: length $\sim 6 \mathrm{~cm}$, ID $7.6 \mathrm{~mm}$, OD $9.4 \mathrm{~mm}$ ) sealed from one end with an arc- welder. The filled $\mathrm{Nb}$ containers were subsequently sealed under reduced Ar pressure with an arc-welder and further sealed under vacuum in evacuated silica tubes (ID $16 \mathrm{~mm}$, OD $18 \mathrm{~mm}$, length $\sim 200 \mathrm{~mm}$, pressure 20 mtorr). The tubes were heated to different temperatures $(773 \mathrm{~K}, 973 \mathrm{~K}, 1073 \mathrm{~K}, 1173 \mathrm{~K})$ with a heating rate of $\sim 1.1$ $\mathrm{K} / \mathrm{min}$, annealed for $48 \mathrm{~h}$ at the desired temperature and furnace cooled to room temperature. The $\mathrm{Nb}$ containers were opened in a glove box. Samples were stored in a glove box to prevent oxidation. To prevent possible over-pressure of the sealed evacuated silica ampoule due to the evolved gas products, two different setups were used. One was to place the sealed $\mathrm{Nb}$ container in the middle of the silica tube with stopcocks at both ends. The silica tube was placed into a horizontal furnace, connected to the flowing $\mathrm{Ar}$ stream (flow rate 30 $\mathrm{mL} / \mathrm{min}$ ), and heated to the desired temperature. To compensate heat uptake by flowing argon, higher annealing temperatures was used (e.g. in order to obtain the desired $1173 \mathrm{~K}$; the temperature was set to $1273 \mathrm{~K}$ ). Alternatively, the silica tube was fitted with a pressure relief check valve and a valve to evacuate the tube and then closed during the annealing (Figure S2).

Additional experiments were conducted to evaluate the possible mechanism of the reaction of hydrides with iron arsenide. The pre-milled mixtures of $\mathrm{BaH}_{2}: \mathrm{FeAs}=1.1: 2$ molar ratio were loaded into a $1 \mathrm{~mL}$ alumina boat with an inverted alumina boat $(1.5 \mathrm{~mL})$ serving as a lid and placed into a silica tube with stopcocks at both ends. The silica tube was placed into a horizontal furnace, connected to the flowing Ar stream (flow rate $30 \mathrm{~mL} / \mathrm{min}$ ), and heated to $973 \mathrm{~K}$ with heating rate of 2.8 $\mathrm{K} / \mathrm{min}$ and held at this temperature for $24 \mathrm{~h}$. To detect any arsine $\left(\mathrm{AsH}_{3}\right)$ gas that might be a potential side product, the argon gas was bubbled through a saturated (concentrated) solution of silver nitrate $\mathrm{AgNO}_{3}$ (Gutzeit test). The color change of the solution from colorless to black indicates presence of evolved arsine according to the equation:

$\mathrm{AsH}_{3}+3 \mathrm{AgNO}_{3} \rightarrow \mathrm{Ag}_{3} \mathrm{As} \downarrow+3 \mathrm{HNO}_{3}$.

CAUTION. The reaction of hydrides with arsenic may under some circumstances result in the formation of acutely toxic and flammable arsine gas $\mathrm{AsH}_{3}$. Appropriate precautions should be taken in the performance of the reactions described.

Characterization. Samples were analyzed by powder X-ray diffraction (powder XRD) on a Bruker D8 Advance X-ray diffractometer in Bragg-Brentano geometry with $\mathrm{Cu} \mathrm{K} \alpha$ radiation $(\lambda=1.54178 \AA)$. Data were collected on a zerobackground plate holder in air. For selected samples high resolution synchrotron powder diffraction data were collected using beamline 11-BM at the Advanced Photon Source (APS), Argonne National Laboratory with an average wavelength of 
$0.413830 \AA$. Discrete detectors covering an angular range from -6 to $16^{\circ} 2 \theta$ were scanned over a $34^{\circ} 2 \theta$ range, with data points collected every $0.001^{\circ} 2 \theta$ with a scan speed of $0.01^{\%}$ s. Samples of $\mathrm{Ba}_{1-\mathrm{x}} \mathrm{K}_{\mathrm{x}} \mathrm{Fe}_{2} \mathrm{As}_{2}$ were mixed with amorphous silica to achieve reasonable transmission and packed in capillaries, which were glued inside an argon-filled glove box. Data were collected at room temperature and additionally at $100 \mathrm{~K}$ for samples with $x=0$ and 0.2 . Diffraction patterns were analyzed by the Rietveld refinement method using the Jana2000 software package. ${ }^{19}$ For each sample the profile parameters, background parameters, zero correction, and lattice constants were refined first. The background was fitted using a shifted 14 or higher-order Chebyshev polynomial function. A pseudo-Voigt function was applied to generate the profile shape. For the $\mathrm{Ba}_{1-}$ ${ }_{x} \mathrm{~K}_{\mathrm{x}} \mathrm{Fe}_{2} \mathrm{As}_{2}$ phase, atomic coordinates and occupancy factors, in particular $\mathrm{Ba} / \mathrm{K}$ ratios and $z$-coordinate for the As position were refined. The preferential orientation of crystallites was taken into account. The results of the Rietveld refinement are listed in Table S1. To get realistic estimated standard deviations (esd's) for $\mathrm{Ba} / \mathrm{K}$ occupancies and unit cell parameters, Berar's factor was applied. $^{20}$

Magnetic susceptibility was measured on a cold-pelletized microcrystalline sample (mass 20-60 mg) with a Quantum Design SQUID magnetometer MPMS-XL. DC magnetic susceptibility measurements were carried out in an applied field of $10 \mathrm{Oe}$ in the $2-200 \mathrm{~K}$ range. The sample was cooled without an external magnetic field applied and then susceptibility was measured at the external field of 10 Oe on heating to $200 \mathrm{~K}$ (ZFC, zero-filed cooled) and on cooling down to $2 \mathrm{~K}$ (FC, field-cooled).

Samples for the TEM study were prepared in the Ar-filled glove box by grinding the material under hexane and depositing a few drops of the suspension onto holey carbon grids. The samples were transported into the microscope column completely avoiding contact with air. The samples were investigated using electron diffraction (ED) and high-resolution highangle annular dark field scanning transmission electron microscopy (HAADF-STEM). The ED patterns were recorded on an FEI Tecnai G2 electron microscope operated at $200 \mathrm{kV}$. The HAADF-STEM images were collected on a probe aberration-corrected microscope FEI Titian 50-80 operated at 200 $\mathrm{kV}$.

Results and Discussion.

Synthesis and characterization of $\mathrm{BaFe}_{2} \mathrm{As}_{2}$ and $\mathrm{KFe}_{2} \mathrm{As}_{2}$ parent compounds. The experimental parameters, such as temperature and hydrides/FeAs ratio, were varied in order to optimize the preparation of single phase samples of $\mathrm{BaFe}_{2} \mathrm{As}_{2}$ and $\mathrm{KFe}_{2} \mathrm{As}_{2}$, while the duration of annealing was kept the same for all synthesis temperatures (48 h). It was determined that ball milling is crucial for the preparation of single phase samples since it provides uniform mixing of initial reagents and it was used in all syntheses. Synthesis of samples $\mathrm{BaFe}_{2} \mathrm{As}_{2}$ and $\mathrm{KFe}_{2} \mathrm{As}_{2}$ was performed by reacting either elemental $\mathrm{Fe}$ and As or pre-synthesized FeAs with corresponding hydrides $\mathrm{BaH}_{2}$ or KH.

Synthesis of $\mathrm{BaFe}_{2} \mathrm{As}_{2}$ was attempted at three different temperatures: $773 \mathrm{~K}, 973 \mathrm{~K}, 1173 \mathrm{~K}$ starting from $\mathrm{BaH}_{2}$ and FeAs. A single phase sample was obtained at $1173 \mathrm{~K}$, while synthesis at lower temperatures led to incomplete reaction and significant leftovers of unreacted FeAs (Table S2). Occasionally, a small excess of $\mathrm{BaH}_{2}$, e.g. $\mathrm{BaH}_{2} / \mathrm{FeAs}=1.1 / 2$ was used, since commercially available $\mathrm{BaH}_{2}$ has $95 \%$ purity. When synthesized from elemental iron and arsenic a larger excess of $\mathrm{BaH}_{2}$ is required. The optimized conditions are summarized in Table 1.

$\mathrm{BaFe}_{2} \mathrm{As}_{2}$ undergoes a spin density wave transition at low temperatures $\left(T_{\mathrm{SDW}}=140 \mathrm{~K}\right)$ accompanied by a structural distortion from $I$-tetragonal cell to $F$-orthorhombic $\left(a_{\text {orthorhombic }} \approx\right.$ $\left.\sqrt{ } 2 a_{\text {tetragonal }} ; c_{\text {orthorhombic }} \approx c_{\text {tetragonal }}\right) .{ }^{4}$ To verify the presence of this structural transition for $\mathrm{BaFe}_{2} \mathrm{As}_{2}$ obtained via hydride route, synchrotron powder XRD data were collected at room temperature and at $100 \mathrm{~K}$ (Table S1, Figure S2).

Table 1. Optimized conditions for synthesis of $\mathbf{B a}_{1}$ ${ }_{x} \mathrm{~K}_{x} \mathrm{Fe}_{2} \mathrm{As}_{2} \quad(0 \leq \mathrm{x} \leq 1)$. Note that excess of hydrides was used.

\begin{tabular}{|c|c|c|c|}
\hline $\begin{array}{l}\text { Refined composi- } \\
\text { tion", nominal } x\end{array}$ & Molar ratios & $\begin{array}{l}\text { Annealing } \\
\text { temperature }\end{array}$ & $\begin{array}{l}\text { Impurity } \\
\text { (wt. \%) }\end{array}$ \\
\hline $\mathrm{BaFe}_{2} \mathrm{As}_{2}$ & $\begin{array}{c}\mathrm{BaH}_{2} / \mathrm{FeAs}=1 / 2 \\
\text { or } 1.1 / 2\end{array}$ & $1073 \mathrm{~K}$ & - \\
\hline $\mathrm{BaFe}_{2} \mathrm{As}_{2}$ & $\begin{array}{c}\mathrm{BaH}_{2} / \mathrm{Fe} / \mathrm{As}= \\
1.2 / 2 / 2\end{array}$ & $1073 \mathrm{~K}$ & - \\
\hline $\mathrm{KFe}_{2} \mathrm{As}_{2}$ & $\mathrm{KH} / \mathrm{FeAs}=1.3 / 2$ & $973 \mathrm{~K}$ & - \\
\hline $\mathrm{KFe}_{2} \mathrm{As}_{2}$ & $\mathrm{KH} / \mathrm{FeAs}=1.3 / 2$ & $773 \mathrm{~K}^{* *}$ & - \\
\hline $\mathrm{KFe}_{2} \mathrm{As}_{2}$ & $\begin{array}{c}\mathrm{KH} / \mathrm{Fe} / \mathrm{As}= \\
1.3 / 2 / 2 \\
\end{array}$ & $973 \mathrm{~K}$ & - \\
\hline \multicolumn{4}{|c|}{$\mathrm{Ba}_{1.1(1-\mathrm{x})} \mathrm{K}_{1.3 \mathrm{x}} \mathrm{Fe}_{2} \mathrm{As}_{2}(\mathrm{FeAs}$ as precursor) } \\
\hline $\begin{array}{c}\mathrm{Ba}_{0.13} \mathrm{~K}_{0.87(5)} \mathrm{Fe}_{2} \mathrm{~A} \\
\mathrm{~s}_{2} \\
x=0.9\end{array}$ & $\begin{array}{c}\mathrm{BaH}_{2} / \mathrm{KH} / \mathrm{FeAs}= \\
0.11 / 1.17 / 2\end{array}$ & $973 \mathrm{~K}$ & - \\
\hline $\begin{array}{c}\mathrm{Ba}_{0.32} \mathrm{~K}_{0.68(6)} \mathrm{Fe}_{2} \mathrm{~A} \\
\mathrm{~s}_{2} \\
x=0.7\end{array}$ & $\begin{array}{c}\mathrm{BaH}_{2} / \mathrm{KH} / \mathrm{FeAs}= \\
0.33 / 0.91 / 2\end{array}$ & $973 \mathrm{~K}$ & - \\
\hline $\begin{array}{c}\mathrm{Ba}_{0.46} \mathrm{~K}_{0.54(4)} \mathrm{Fe}_{2} \mathrm{~A} \\
\mathrm{~s}_{2} \\
x=0.5\end{array}$ & $\begin{array}{c}\mathrm{BaH}_{2} / \mathrm{KH} / \mathrm{FeAs}= \\
0.55 / 0.65 / 2\end{array}$ & $973 \mathrm{~K}$ & - \\
\hline $\begin{array}{c}\mathrm{Ba}_{0.61} \mathrm{~K}_{0.39(3)} \mathrm{Fe}_{2} \mathrm{~A} \\
\mathrm{~s}_{2} \\
x=0.4\end{array}$ & $\begin{array}{c}\mathrm{BaH}_{2} / \mathrm{KH} / \mathrm{FeAs}= \\
0.66 / 0.52 / 2\end{array}$ & $1073 \mathrm{~K}$ & - \\
\hline $\begin{array}{c}\mathrm{Ba}_{0.88} \mathrm{~K}_{0.12(5)} \mathrm{Fe}_{2} \mathrm{~A} \\
\mathrm{~s}_{2} \\
x=0.2\end{array}$ & $\begin{array}{c}\mathrm{BaH}_{2} / \mathrm{KH} / \mathrm{FeAs}= \\
0.88 / 0.26 / 2\end{array}$ & $1073 \mathrm{~K}$ & FeAs (2) \\
\hline \multicolumn{4}{|c|}{$\mathrm{Ba}_{1.1(1-\mathrm{x})} \mathrm{K}_{1.3 \mathrm{x}} \mathrm{Fe}_{2} \mathrm{As}_{2}$ (elemental $\mathrm{Fe}$ and As as precursors) } \\
\hline $\begin{array}{c}\mathrm{Ba}_{0.32} \mathrm{~K}_{0.65(5)} \mathrm{Fe}_{2} \mathrm{~A} \\
\mathrm{~s}_{2} \\
x=0.7\end{array}$ & $\begin{array}{c}\mathrm{BaH}_{2} / \mathrm{KH} / \mathrm{Fe} / \mathrm{As}= \\
0.33 / 0.91 / 2 / 2\end{array}$ & $973 \mathrm{~K}$ & $\begin{array}{c}\mathrm{Fe}_{2} \mathrm{As} \\
\text { (3) }\end{array}$ \\
\hline $\begin{array}{c}\mathrm{Ba}_{0.46} \mathrm{~K}_{0.52(6)} \mathrm{Fe}_{2} \mathrm{~A} \\
\mathrm{~s}_{2} \\
x=0.5\end{array}$ & $\begin{array}{c}\mathrm{BaH}_{2} / \mathrm{KH} / \mathrm{Fe} / \mathrm{As}= \\
0.55 / 0.65 / 2 / 2\end{array}$ & $973 \mathrm{~K}$ & $\begin{array}{l}\mathrm{Fe}_{2} \mathrm{As} \\
\text { (6) }\end{array}$ \\
\hline $\begin{array}{c}\mathrm{Ba}_{0.76} \mathrm{~K}_{0.22(4)} \mathrm{Fe}_{2} \mathrm{~A} \\
\mathrm{~s}_{2} \\
x=0.3\end{array}$ & $\begin{array}{c}\mathrm{BaH}_{2} / \mathrm{KH} / \mathrm{Fe} / \mathrm{As}= \\
0.77 / 0.39 / 2 / 2\end{array}$ & $1073 \mathrm{~K}$ & $\begin{array}{l}\mathrm{Fe}_{2} \mathrm{As} \\
\quad(5)\end{array}$ \\
\hline
\end{tabular}

*Starting materials were ball milled for $30 \mathrm{~min}$ and annealed for 2 days (see experimental section for details).

*** Sample prepared at $773 \mathrm{~K}$ exhibits lower crystallinity resulting in broader XRD peaks and slight variation in unit cell parameters.

${ }^{\#}$ Composition determined by Rietveld refinement (see Table S1 and experimental section).

The splitting of several reflections, for instance (110) and (112) upon cooling down to $100 \mathrm{~K}$ indicates the I-tetragonal cell to $F$-orthorhombic structural distortion (Figure 2, top) similar to that reported for $\mathrm{BaFe}_{2} \mathrm{As}_{2}$ prepared from elements. ${ }^{4}$ 
Optimization of synthesis conditions was performed for $\mathrm{KFe}_{2} \mathrm{As}_{2}$ starting from $\mathrm{KH}$ and $\mathrm{FeAs}$ (Table S2). Synthesis at $1173 \mathrm{~K}$ results in the presence of $\mathrm{Fe}_{2} \mathrm{As}$ and $\mathrm{K}_{3} \mathrm{As}$ impurities, suggesting that the annealing at $1173 \mathrm{~K}$ leads to the partial decomposition of $\mathrm{KFe}_{2} \mathrm{As}_{2}$, and therefore this temperature is too high. It was determined that an excess of $\mathrm{KH}$ is needed, since synthesis with $\mathrm{KH}: \mathrm{FeAs}$ ratio of 1:2 leads to the presence of residual FeAs. The synthesis temperature was lowered to $973 \mathrm{~K}$ and excess $\mathrm{KH}$ was used. The optimized conditions for synthesis of $\mathrm{KFe}_{2} \mathrm{As}_{2}$ phase can be summarized as follows: $\mathrm{KH}: \mathrm{FeAs}$ in the ratio of 1.3:2, ball milled for $30 \mathrm{~min}$, and annealed at $973 \mathrm{~K}$ for $48 \mathrm{~h}$. A single phase sample of $\mathrm{KFe}_{2} \mathrm{As}_{2}$ can be obtained at temperatures as low as $773 \mathrm{~K}$ (Table 1), but the product exhibits lower crystallinity resulting in broader XRD peaks and slight variation in unit cell parameters (Figure $\mathrm{S} 3)$.
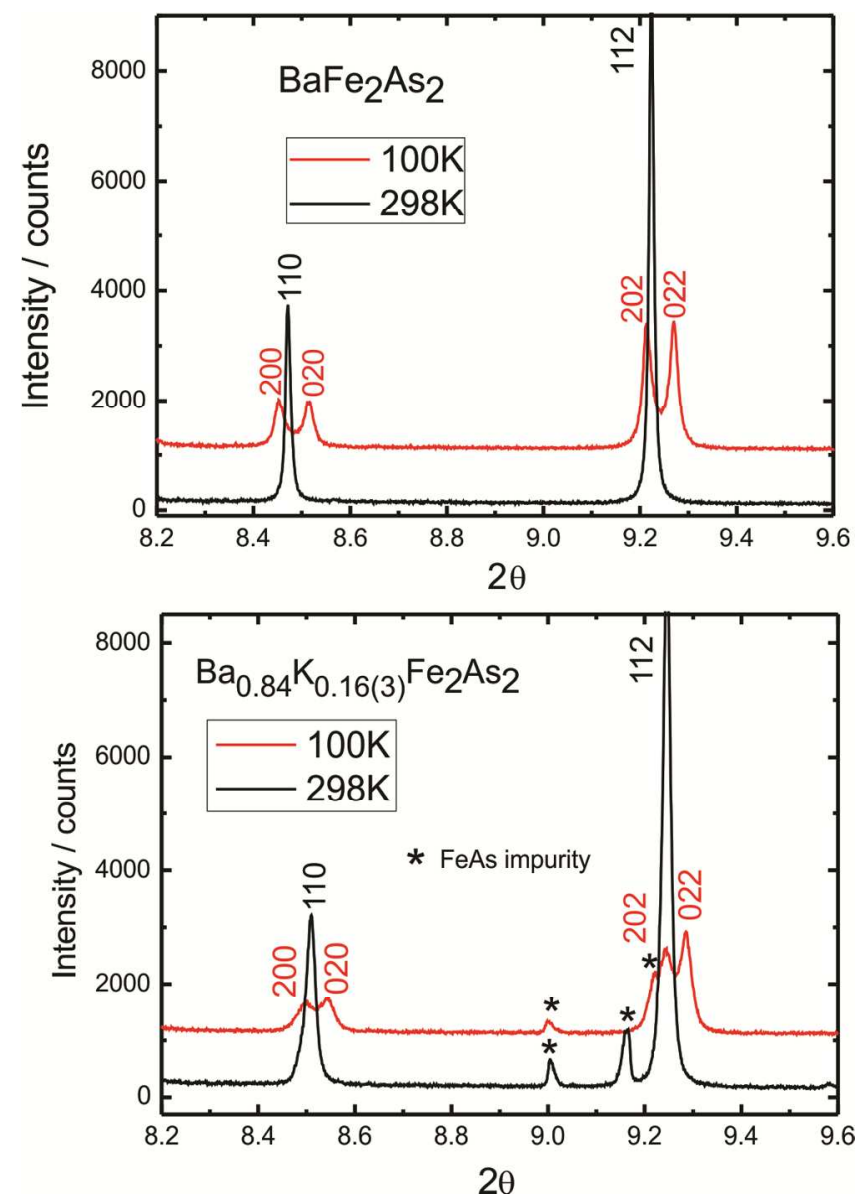

Figure 2. Splitting of (110) and (112) reflections for $\mathrm{BaFe}_{2} \mathrm{As}_{2}$ (top) and $\mathrm{Ba}_{0.84} \mathrm{~K}_{0.16(3)} \mathrm{Fe}_{2} \mathrm{As}_{2}$ (bottom) upon cooling from room temperature( black) to $100 \mathrm{~K}$ (red).

For the ternary $\mathrm{KFe}_{2} \mathrm{As}_{2}$ prepared via the hydride route, we observe variation in the unit cell parameters beyond their uncertainties, suggesting a homogeneity range for this phase. Refinement of atomic occupancies results in only slight deviation from unity for the $\mathrm{K}$ (s.o.f. $98 \pm 1 \%$ ) or $\mathrm{Fe}$ (s.o.f. $92 \pm 6$ $\%)$ atomic sites. The single phase sample of $\mathrm{KFe}_{2} \mathrm{As}_{2}$ can be synthesized not only from the FeAs precursor, but also from elemental $\mathrm{Fe}$ and As with addition of excess of $\mathrm{KH}$ at $973 \mathrm{~K}$ (Table 1). $\mathrm{KFe}_{2} \mathrm{As}_{2}$ prepared via the hydride route is air and moisture sensitive similar to $\mathrm{KFe}_{2} \mathrm{As}_{2}$ prepared from ele- ments. ${ }^{21}$ When left in air, it decomposes into $\mathrm{KAsO}_{3}$ and hydrated $\mathrm{Fe}_{2} \mathrm{O}_{3}$.

An excess of hydrides $\left(\mathrm{BaH}_{2}\right.$ or $\left.\mathrm{KH}\right)$ is necessary to produce single phase samples in case of $\mathrm{KFe}_{2} \mathrm{As}_{2}$ and $\mathrm{BaFe}_{2} \mathrm{As}_{2}$. This can be attributed to several reasons: the commercially available hydrides have 95-97\% purity and thus may contain small amounts of oxidation products. Additionally, due to its volatility, excessive potassium may be deposited on the walls of the niobium crucible. Notably, excess of the corresponding metals (Ba) was used for synthesis of $\mathrm{BaFe}_{2} \mathrm{As}_{2}$ from the elements. ${ }^{4}$ Additionally, significant excess of hydrides is required for the preparation of Zintl phases, $\mathrm{Na}_{4} \mathrm{Si}_{4}, \mathrm{Na}_{4} \mathrm{Ge}_{4}$ and $\mathrm{K}_{4} \mathrm{Ge}_{4}$ from $\mathrm{Si}$ or $\mathrm{Ge}$ and corresponding $\mathrm{NaH}$ and $\mathrm{KH}$ hydrides. ${ }^{17}$

Synthesis and characterization of $\mathrm{Ba}_{1-x} \mathrm{~K}_{\mathrm{x}} \mathrm{Fe}_{2} \mathrm{As}_{2}$.

Once the synthesis of the ternary $\mathrm{BaFe}_{2} \mathrm{As}_{2}$ and $\mathrm{KFe}_{2} \mathrm{As}_{2}$ was optimized, the solid solution $\mathrm{Ba}_{1-\mathrm{x}} \mathrm{K}_{\mathrm{x}} \mathrm{Fe}_{2} \mathrm{As}_{2}$ was prepared following a similar procedure. An excess of $\mathrm{KH}$ and $\mathrm{BaH}_{2}$ was used, leading to the nominal composition $\mathrm{Ba}_{1.1(1-x)} \mathrm{K}_{1.3 \mathrm{x}} \mathrm{Fe}_{2} \mathrm{As}_{2}$. The annealing temperature was initially chosen as $973 \mathrm{~K}$, however for K-poor compositions ( $\mathrm{x} \leq 0.4)$, synthesis at $973 \mathrm{~K}$ resulted in the presence of residual $\mathrm{FeAs}$, while annealing at $1073 \mathrm{~K}$ led to nearly single phase product. Similarly to the parent ternary compounds, the synthesis of $\mathrm{Ba}_{1-\mathrm{x}} \mathrm{K}_{\mathrm{x}} \mathrm{Fe}_{2} \mathrm{As}_{2}$ from elements requires an excess of the corresponding hydrides (Table 1).

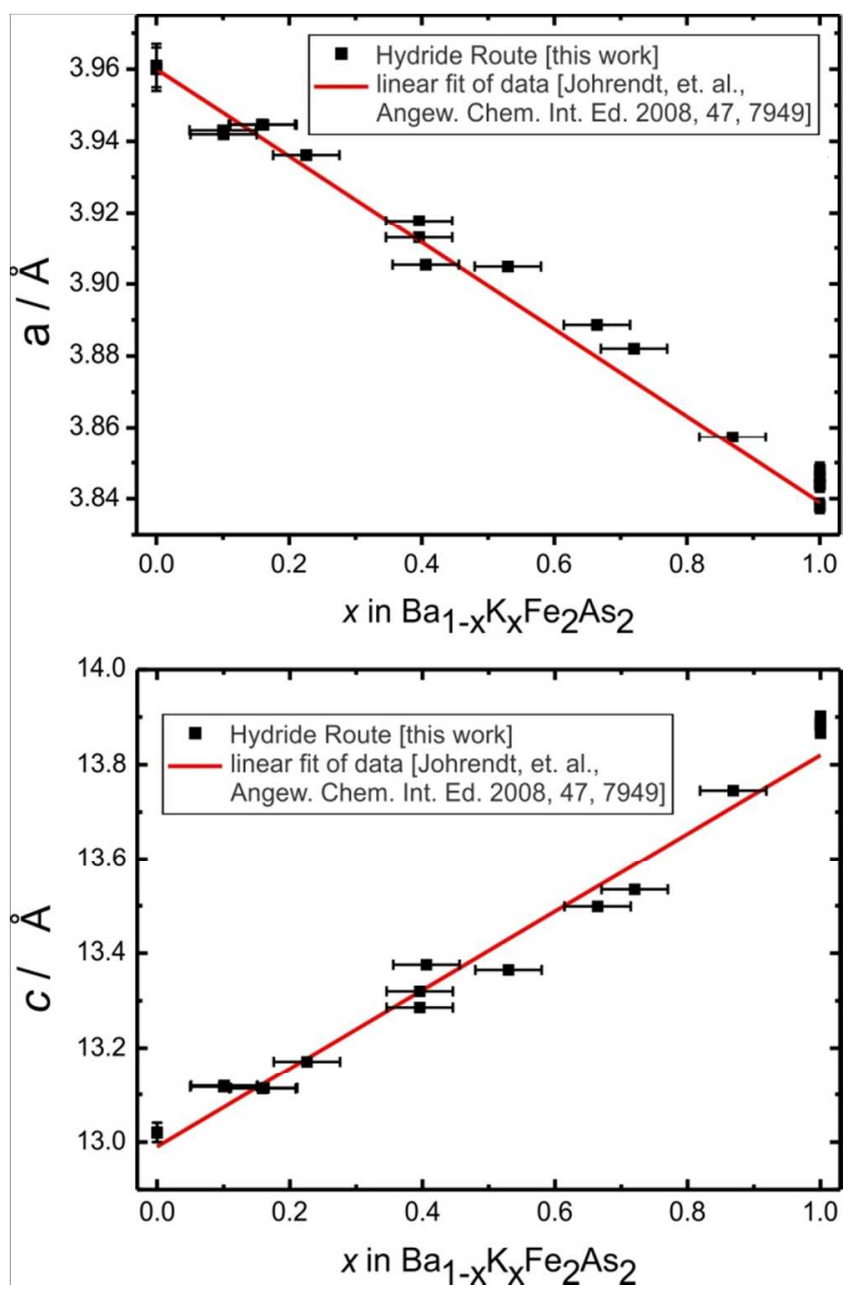

Figure 3. Variation of unit cell parameters with potassium content, $x$, in $\mathrm{Ba}_{1-\mathrm{x}} \mathrm{K}_{\mathrm{x}} \mathrm{Fe}_{2} \mathrm{As}_{2}$. For comparison linear fit of data 
by Johrendt et al. ${ }^{7}$ is plotted as red line. Error bars for the unit cell parameters are smaller than the symbols used for the experimental data.

The formation of $\mathrm{Ba}_{1-\mathrm{x}} \mathrm{K}_{\mathrm{x}} \mathrm{Fe}_{2} \mathrm{As}_{2}$ from hydrides and $\mathrm{FeAs}$ can be described by the following equation:

$(1-\mathrm{x}) \mathrm{BaH}_{2}+\mathrm{x} \mathrm{KH}+2 \mathrm{FeAs} \rightarrow \mathrm{Ba}_{1-\mathrm{x}} \mathrm{K}_{\mathrm{x}} \mathrm{Fe}_{2} \mathrm{As}_{2}+(1-\mathrm{x} / 2) \mathrm{H}_{2} \uparrow$, which implies that hydrogen gas is evolved during synthesis. According to the Gutzeit test, which is used to detect arsenic in the form of arsine $\mathrm{AsH}_{3}$, no arsine is evolved during heat treatment of $\mathrm{BaH}_{2}$ and $\mathrm{FeAs}$. $\mathrm{Nb}$ is known to be permeable to hydrogen and $\mathrm{Nb}$-based alloys have been suggested to use for hydrogen permeable membranes. ${ }^{22-24}$ Starting components were annealed in a sealed $\mathrm{Nb}$ tube encapsulated in a evacuated silica tube. Since hydrogen is being evolved during the reaction, leading to the buildup of the pressure in the silica tube, larger amounts (>0.5 g) of the starting materials can be annealed under flow of argon gas or with a pressure relief valve (Figure S1).

Refinement of the $\mathrm{Ba} / \mathrm{K}$ ratio in $\mathrm{Ba}_{1-\mathrm{x}} \mathrm{K}_{\mathrm{x}} \mathrm{Fe}_{2} \mathrm{As}_{2}$ samples using laboratory or synchrotron powder XRD data revealed that the nominal composition is close to the actual one obtained from the refinement (Table 1 and S1). The dependence of the tetragonal unit cell parameters, $a$ and $c$, upon $\mathrm{K}$ content, $x$, is linear in accordance with Vegard's law with $a$ parameter decreasing, and $c$ parameter increasing with increase of $\mathrm{K}$ content, $x$ (Figure 3 ). Considering the error bars, the unit cell parameters for $\mathrm{Ba}_{1-\mathrm{x}} \mathrm{K}_{\mathrm{x}} \mathrm{Fe}_{2} \mathrm{As}_{2}$ prepared via hydride route are identical to those for $\mathrm{Ba}_{1-\mathrm{x}} \mathrm{K}_{\mathrm{x}} \mathrm{Fe}_{2} \mathrm{As}_{2}$ prepared by standard solid state techniques from elements.

Doping with potassium is known to suppress the spin density wave transition and structural distortion from I-tetragonal to $F$-orthorhombic cell and induces superconductivity at low temperatures. ${ }^{7,11}$ However for low potassium concentrations $(x$ $\leq 0.2$ ) a structural transition from tetragonal to orthorhombic phase still takes place. ${ }^{7}$ Synchrotron powder XRD data collected at room temperature and at $100 \mathrm{~K}$ (Table S1, Figure S2) for a $\mathrm{Ba}_{0.84} \mathrm{~K}_{0.16(3)} \mathrm{Fe}_{2} \mathrm{As}_{2}$ sample prepared via hydride route indicate the splitting of (110) and (112) reflections upon cooling to $100 \mathrm{~K}$ (Figure 2, bottom). This is consistent with $\mathrm{I}$ tetragonal to $F$-orthorhombic structural distortion similar to that reported for $\mathrm{Ba}_{0.8} \mathrm{~K}_{0.2} \mathrm{Fe}_{2} \mathrm{As}_{2}$ prepared from elements. ${ }^{7}$

Alkaline-earth and rare-earth metal hydrides, $\mathrm{CaH}_{2}, \mathrm{LaH}_{2}$, $\mathrm{CeH}_{2}$ and $\mathrm{SmH}_{2}$ have been used for the high-pressure synthesis of other representatives of the iron arsenide superconductors family, $\mathrm{LnFeAsF}_{1-x} \mathrm{H}_{x} \quad(x=0.0-1.0 ; \mathrm{Ln}=\mathrm{Ca}$ or $\mathrm{La})$ and $\mathrm{LnFeAsO}_{1-x} \mathrm{H}_{x}(\mathrm{Ln}=\mathrm{Ca}, \mathrm{La}, \mathrm{Ce}, \mathrm{Sm}) .{ }^{25-27}$ For this preparation, high pressure ( 2 GPa) and high temperatures (up to $1473 \mathrm{~K}$ ) as well as a supplementary hydrogen source $\left(\mathrm{LiBH}_{4}\right.$ or $\mathrm{NaBH}_{4}$ ) are required to force $\mathrm{H}^{-}$ions to occupy $\mathrm{F}^{-}$sites between FeAs layers. In the case of $\mathrm{LnFeAsO}_{1-\mathrm{x}} \mathrm{H}_{\mathrm{x}}(\mathrm{Ln}=\mathrm{Ca}, \mathrm{La}$, $\mathrm{Ce}, \mathrm{Sm})$ the hydrogen substitution as $\mathrm{H}^{-}$into the $\mathrm{O}^{2-}$ site provides excess electrons to the FeAs layer, giving rise to superconductivity with a maximum $T_{\mathrm{c}}$ of $56 \mathrm{~K}$ for SmFeA$\mathrm{sO}_{0.75} \mathrm{H}_{0.25}$. Incorporation of hydrogen into $\mathrm{SmFeAsO}$ leads to substantial contraction of the unit cell volume and subsequent change of the electronic properties due to hydrogen doping, which results in a concomitant change in $T_{c}$. We do not see any variation of unit cell parameters for $\mathrm{Ba}_{1-\mathrm{x}} \mathrm{K}_{\mathrm{x}} \mathrm{Fe}_{2} \mathrm{As}_{2}$ prepared by the hydride route. To further confirm the absence of hydrogen doping, samples of $\mathrm{Ba}_{1-\mathrm{x}} \mathrm{K}_{\mathrm{x}} \mathrm{Fe}_{2} \mathrm{As}_{2}$ have been analyzed by magnetometry.
Magnetic properties. $\mathrm{BaFe}_{2} \mathrm{As}_{2}$ prepared via hydride route exhibits weak, slightly temperature-dependent paramagnetism with a small magnetic anomaly at around $140 \mathrm{~K}$, which is associated with spin-density wave transition (Figure S4a). This is consistent with the literature data on powdered sample of $\mathrm{BaFe}_{2} \mathrm{As}_{2}$ made from elements. ${ }^{4}$ The powdered sample of $\mathrm{KFe}_{2} \mathrm{As}_{2}$ shows the sharp onset of superconducting transition for both ZFC and FC curves at $T_{\mathrm{c}}=3.5 \mathrm{~K}$ (Figure $\mathrm{S} 4 \mathrm{~b}$ ); the superconducting transition temperature is concordant with the literature data. ${ }^{28-31}$

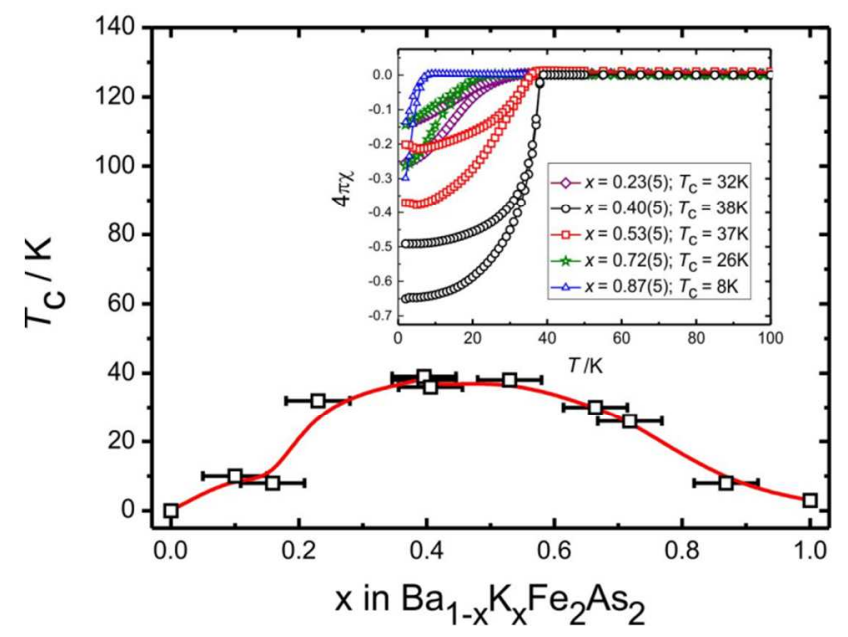

Figure 4. Compositional dependence of superconducting transition temperature, $T_{\mathrm{c}}$, upon potassium content, $\mathbf{x}$, in $\mathrm{Ba}_{1}$ ${ }_{x} \mathrm{~K}_{x} \mathrm{Fe}_{2} \mathrm{As}_{2}$. Insert: temperature dependence of magnetization measured in the applied field of $10 \mathrm{Oe}$.

Bulk superconductivity in the samples of $\mathrm{Ba}_{1-\mathrm{x}} \mathrm{K}_{\mathrm{x}} \mathrm{Fe}_{2} \mathrm{As}_{2}$ was observed for all the compositions with $x>0.2$, as is evident from the temperature dependence of magnetic susceptibility (Figure 4, insert). Superconducting transitions are sharp for samples with doping level close to optimum, $x \approx 0.4$, while for $x$ close to 0.2 and 0.7 , transitions are somewhat broader. The superconducting volume fractions correspond to $65 \%$ for the optimal $\mathrm{K}$ concentration. The superconducting transition temperature, $T_{\mathrm{c}}$, has been calculated from the onset of superconducting transitions, and has a strong dependence on $\mathrm{K}$ content, reaching a maximum of $38 \mathrm{~K}$ for $x$ close to 0.4 . The dependence of $T_{\mathrm{c}}$ has characteristic dome-like dependence upon $\mathrm{K}$ content analogous to that for $\mathrm{Ba}_{1-\mathrm{x}} \mathrm{K}_{\mathrm{x}} \mathrm{Fe}_{2} \mathrm{As}_{2}$ prepared from elements. $^{7}$

Transmission Electron Microscopy. The variation of the Kconcentration is believed to be one of the crucial factors governing the observed electronic inhomogenties and phase separations into magnetically ordered and superconducting phases. ${ }^{32-36}$ Potassium dopant clustering and nanoscale inhomogenties have been detected by atom probe tomography ${ }^{37}$ on the surfaces of $\mathrm{Ba}_{0.72} \mathrm{~K}_{0.28} \mathrm{Fe}_{2} \mathrm{As}_{2}$ crystals obtained from FeAs flux and $\mathrm{Sr}_{0.75} \mathrm{~K}_{0.25} \mathrm{Fe}_{2} \mathrm{As}_{2}$ crystals by scanning tunneling microscopy. ${ }^{34}$ Since hydrides provide better mixing, the distribution of the K-dopant is expected to be more homogeneous. To study the $\mathrm{Ba} / \mathrm{K}$ distribution, samples of $\mathrm{Ba}_{0.5} \mathrm{~K}_{0.5} \mathrm{Fe}_{2} \mathrm{As}_{2}$ and $\mathrm{Ba}_{0.6} \mathrm{~K}_{0.4} \mathrm{Fe}_{2} \mathrm{As}_{2}$ were analyzed by means of ED and HAADFSTEM. To the best of our knowledge, this is the first example of detailed investigation of $\mathrm{Ba}_{1-\mathrm{x}} \mathrm{K}_{\mathrm{x}} \mathrm{Fe}_{2} \mathrm{As}_{2}$ by HAADF-STEM.

Typical ED patterns taken along the [001], [100] and [110] crystallographic axes of the structure for the sample 
$\mathrm{Ba}_{0.5} \mathrm{~K}_{0.5} \mathrm{Fe}_{2} \mathrm{As}_{2}$ (Figure 5) can be consistently indexed in a tetragonal lattice with the cell parameters $a \sim 3.8 \AA, c \sim 13.1$ $\AA$ and $I 4 / \mathrm{mmm}$ space group, which agrees with powder XRD data. The ED patterns for the $\mathrm{Ba}_{0.6} \mathrm{~K}_{0.4} \mathrm{Fe}_{2} \mathrm{As}_{2}$ sample look the same and are given in Supporting Information (Figure S5).
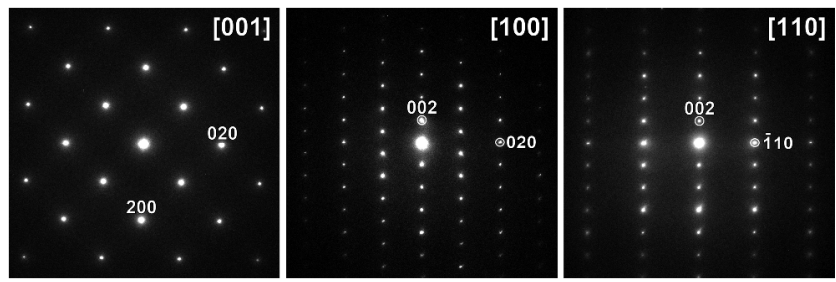

Figure 5. ED patterns along the main crystallographic axes of the $\mathrm{Ba}_{0.5} \mathrm{~K}_{0.5} \mathrm{Fe}_{2} \mathrm{As}_{2}$ structure.
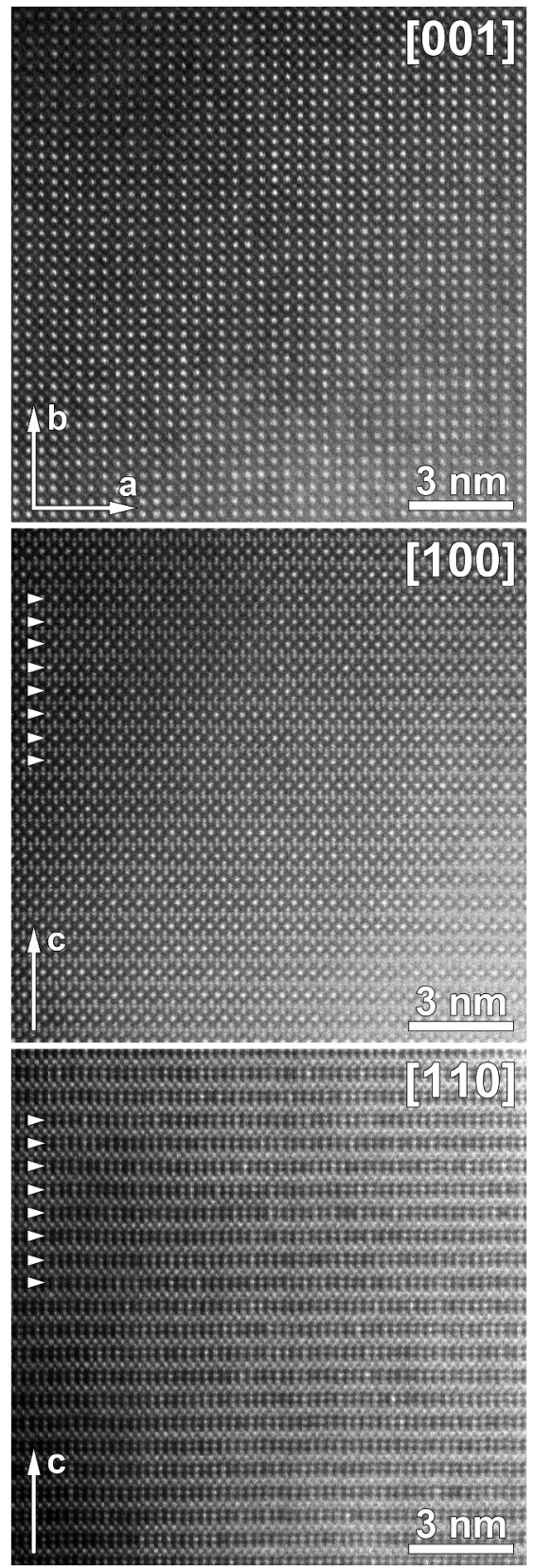

Figure 6. HAADF-STEM images for the $\mathrm{Ba}_{0.5} \mathrm{~K}_{0.5} \mathrm{Fe}_{2} \mathrm{As}_{2}$ sample taken along [001], [100] and [110] zone axes. Arrowheads indicate the $\mathrm{Ba} / \mathrm{K}$ layers in the structure. The structure looks homogeneous along [001] and [100] directions, while along the [110] direction some $\mathrm{Ba} / \mathrm{K}$ columns appear noticeably brighter or weaker than the others, indicating slightly inhomogeneous $\mathrm{Ba} / \mathrm{K}$ distribution.

HAADF-STEM images for $\mathrm{Ba}_{0.5} \mathrm{~K}_{0.5} \mathrm{Fe}_{2} \mathrm{As}_{2}$ taken along the [001], [100] and [110] directions are shown in Figure 6. In this microscopy technique the intensity scales approximately as $I \sim$ $Z^{2}$, where $Z$ is an average atomic number of the projected column. HAADF-STEM images can provide the information on the distribution of atomic species in the structure $\left(Z_{\mathrm{Ba}}=56, Z_{\mathrm{K}}\right.$ $\left.=19, Z_{\mathrm{Fe}}=26, Z_{\mathrm{As}}=33\right)$. Images taken along the [001] and [100] zone axes do not indicate any $\mathrm{Ba} / \mathrm{K}$ ordering and therefore their distribution is completely homogeneous being viewed along these directions. The HAADF-STEM image along the [110] zone axis demonstrates differences in the intensity of the dots attributed to the $\mathrm{Ba} / \mathrm{K}$ columns $(\mathrm{Ba} / \mathrm{K}$ layers are pointed with arrowheads). Using the HAADF-STEM images, we measured the intensities associated with the columns corresponding to $\mathrm{Ba} / \mathrm{K}$ and $\mathrm{Fe}$. The intensity distribution is plotted in Figure S6. The intensity spread of the Fe columns can be attributed to the variable thickness of the crystal. One can expect the same intensity spread for the $\mathrm{Ba} / \mathrm{K}$ columns for the completely homogeneous $\mathrm{Ba} / \mathrm{K}$ distribution, but the observed intensity variation of the $\mathrm{Ba} / \mathrm{K}$ columns is noticeably broader, indicating that some columns are Ba-enriched, whereas some are Ba-depleted. However, in general the occurrence of such columns seems to be random in the structure.

In the enlarged [110] HAADF-STEM image in Figure 7, only two areas (marked with brackets) demonstrate ordered alternation between Ba-depleted (indicated with white arrows at the intensity profiles) and Ba-enriched columns (indicated with black arrows). Such alternation would lead to a $\sqrt{2} a \times \sqrt{ } 2 a \times c$ superstructure, with the [001] projection shown in Figure 8. The complete set of the profiles measured for the $\mathrm{Ba} / \mathrm{K}$ layers are shown in Supporting Information (Figure S7). No pronounced $\mathrm{Ba} / \mathrm{K}$ ordering was observed on the HAADF-STEM images taken for the $\mathrm{Ba}_{0.6} \mathrm{~K}_{0.4} \mathrm{Fe}_{2} \mathrm{As}_{2}$ sample (Figures $\mathrm{S} 8$ and S9).

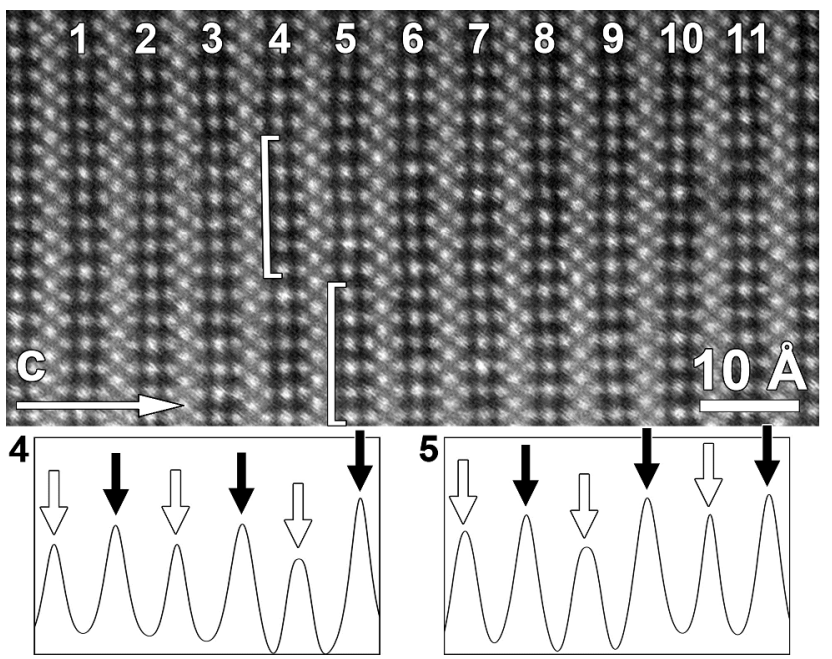

Figure 7. Enlarged [110] HAADF-STEM image for the $B a_{0.5} K_{0.5} F_{2} A_{2}$ sample with marked $B a / K$ layers $1-11$. The intensity profiles were measured from the parts marked with brackets in layers 4 and 5. Alternation of the Ba-enriched and 
Ba-depleted columns is marked with black and white arrows, respectively. No specific ordering occurs for the rest of the layers.

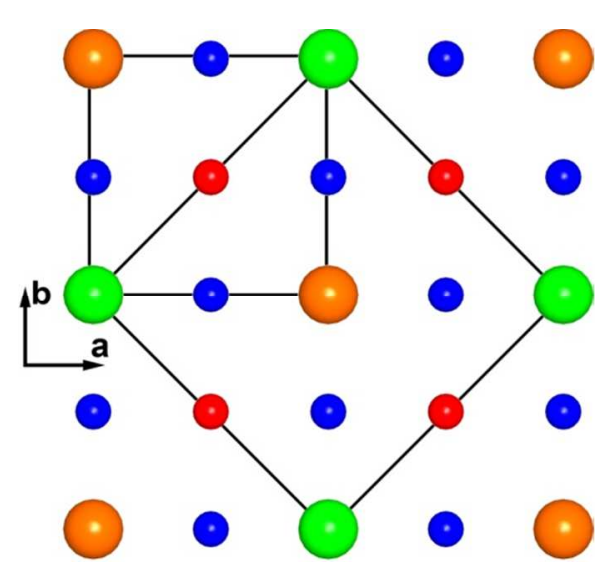

Figure 8. Scheme of the $\mathrm{Ba} / \mathrm{K}$ ordering in $\mathrm{Ba}_{0.5} \mathrm{~K}_{0.5} \mathrm{Fe}_{2} \mathrm{As}_{2}$ viewed along the [001] direction. The unit cells of the basic $a \times a \times c$ structure and of the $\sqrt{2} a \times \sqrt{2} a \times c$ superstructure are outlined. Ba: green, K: orange, Fe: blue, As: red.

ED and HAADF-STEM study of $\mathrm{Ba}_{0.5} \mathrm{~K}_{0.5} \mathrm{Fe}_{2} \mathrm{As}_{2}$ and $\mathrm{Ba}_{0.6} \mathrm{~K}_{0.4} \mathrm{Fe}_{2} \mathrm{As}_{2}$ samples prepared from hydrides revealed high crystallinity of the product and absence of significant $\mathrm{Ba} / \mathrm{K}$ clustering, thus confirming the appropriatness of hydride route for the preparation of $\mathrm{Ba}_{1-\mathrm{x}} \mathrm{K}_{\mathrm{x}} \mathrm{Fe}_{2} \mathrm{As}_{2}$ superconductors. Local ordering along [110] crystallographic direction can be an intrinsic property or a kinetically-induced phenomenon. More studies are currently underway, including high-temperature calorimetric investigations.

Discussion. Several methods of preparation of $\mathrm{Ba}_{1-\mathrm{x}} \mathrm{K}_{\mathrm{x}} \mathrm{Fe}_{2} \mathrm{As}_{2}$ in powdered bulk or in the form of single crystals are reported due to date. ${ }^{15}$ Single crystals can be grown from FeAs flux, or KAs-flux (for K-rich compositions) or Sn-flux. The latter is less preferable, since tin inclusions into the crystal structure of $\mathrm{Ba}_{1-\mathrm{x}} \mathrm{K}_{\mathrm{x}} \mathrm{Fe}_{2} \mathrm{As}_{2}$ affect its properties. While flux methods give access to large crystals suitable for property measurement, these methods are not suitable for the production of bulk samples or wires.

The classical solid state method to produce bulk materials involves combining elemental $\mathrm{Ba}, \mathrm{K}, \mathrm{Fe}$, As and heating them in inert atmosphere. This method requires multiple annealing, pressing of the pellets, and re-grinding in order to achieve a homogeneous distribution of reactants and improve slow kinetics. In some cases, to minimize the loss of potassium by evaporation, the volume of the alumina crucibles is reduced by alumina inlays. All these precautions are needed owing to the drastically different reactivity of the starting reagents: volatile As (sublimes at $887 \mathrm{~K}$ ), low-melting and volatile K (mp 336 $\mathrm{K}$; bp $1032 \mathrm{~K})$ and quite inert $\mathrm{Fe}(\mathrm{mp} 1811 \mathrm{~K})$. The reaction $\mathrm{Ba}+\mathrm{K}+\mathrm{Fe}+\mathrm{As} \rightarrow \mathrm{Ba}_{1-\mathrm{x}} \mathrm{K}_{\mathrm{x}} \mathrm{Fe}_{2} \mathrm{As}_{2}$ proceeds through the solid state, and homogeneous mixing of all the starting materials is important. Given the nature of potassium as a soft sticky met$\mathrm{al}$, the mixing of the elemental $\mathrm{Ba}, \mathrm{K}, \mathrm{Fe}$, As can be an issue. To overcome this difficulty, binary arsenides, KAs, BaAs and $\mathrm{Fe}_{2} \mathrm{As}$ have been suggested as precursors, ${ }^{16}$ however the precursors are not commercially available and need to be synthesized. Salt-like barium and potassium hydrides are suitable precursors for the synthesis of $\mathrm{Ba}_{1-\mathrm{x}} \mathrm{K}_{\mathrm{x}} \mathrm{Fe}_{2} \mathrm{As}_{2}$ since they pro- vide better mixing of the components. After decomposition of $\mathrm{KH}(\sim 673 \mathrm{~K})$, the resulting potassium is already intimately mixed with Fe/As, thus leading to faster formation of the target phase. According to powder XRD and magnetic data, $\mathrm{Ba}_{1 \text { - }}$ ${ }_{\mathrm{x}} \mathrm{K}_{\mathrm{x}} \mathrm{Fe}_{2} \mathrm{As}_{2}$ prepared from hydrides has the same structural and superconducting properties as $\mathrm{Ba}_{1-\mathrm{x}} \mathrm{K}_{\mathrm{x}} \mathrm{Fe}_{2} \mathrm{As}_{2}$ obtained from elements. The hydride route is being suggested for the preparation of the superconducting $\mathrm{Ba}_{1-\mathrm{x}} \mathrm{K}_{\mathrm{x}} \mathrm{Fe}_{2} \mathrm{As}_{2}$ wires by the in situ powder-in-tube method owing to its simplicity and fast kinetics. This method can be also extended to other iron arsenide superconductors, such as $\mathrm{BaFe}_{2-\mathrm{x}} \mathrm{Co}_{\mathrm{x}} \mathrm{As}_{2}$, where slow kinetics is known to be an issue, as well as to other arsenides, such as NaFeAs and LiFeAs, and even superconducting selenides, such as $\mathrm{KFe}_{2} \mathrm{Se}_{2}$.

Conclusion. We have developed an efficient and easy method of preparation of superconducting $\mathrm{Ba}_{1-\mathrm{x}} \mathrm{K}_{\mathrm{x}} \mathrm{Fe}_{2} \mathrm{As}_{2}$ from the hydrides $\mathrm{BaH}_{2}$ and $\mathrm{KH}$. This method is a simple and fast alternative to the traditional solid state route and includes short ball milling of corresponding hydrides and either FeAs or elemental $\mathrm{Fe}$ and $\mathrm{As}$ and heat treatment at $973 \mathrm{~K}$ or $1073 \mathrm{~K}$ in sealed $\mathrm{Nb}$ containers. The hydride route to $\mathrm{Ba}_{1-\mathrm{x}} \mathrm{K}_{\mathrm{x}} \mathrm{Fe}_{2} \mathrm{As}_{2}$ can be explored for the preparation of superconducting $\mathrm{Ba}_{1-}$ ${ }_{x} \mathrm{~K}_{\mathrm{x}} \mathrm{Fe}_{2} \mathrm{As}_{2}$ wires by the in situ powder-in-tube method owing to its simplicity and fast kinetics. This method can be also extended to other iron arsenide superconductors as well as some selenides because of the availability of the corresponding hydrides and versatility of the proposed method.

\section{ASSOCIATED CONTENT}

Tables S1-S2 and Figures S1-S9. This material is available free of charge via the Internet at http://pubs.acs.org.

\section{AUTHOR INFORMATION}

\section{Corresponding Author}

* Prof. Dr. Susan M. Kauzlarich; smkauzlarich@ucdavis.edu Dr. Julia V. Zaikina; yzaikina@ucdavis.edu

\section{Author Contributions}

The manuscript was written through contributions of all authors. All authors have given approval to the final version of the manuscript.

\section{Funding Sources}

Financial support from the NSF (Grant NSF DMR-1100313) is gratefully acknowledged. JVZ thanks UC Davis for financial support. Use of the Advanced Photon Source at Argonne National Laboratory was supported by the U. S. Department of Energy, Office of Science, Office of Basic Energy Sciences, under Contract No. DE-AC02-06CH11357.

Notes

The authors declare no competing financial interest

\section{ACKNOWLEDGMENT}

We thank Peter Klavins (UC Davis) for assistance with the SQUID measurements and Dr. Mike Hayward (Inorganic Chemistry Laboratory at Oxford University) for advice on the pressure relief apparatus.

\section{REFERENCES}

1. Johnston, D.C. Adv. Phys. 2010, 59, 803-1061.

2. Kamihara, Y.; Watanabe, T.; Hirano, M.;Hosono, H. J. Am. Chem. Soc. 2008, 130, 3296-3297. 
3. Ganguli, A.K.; Prakash, J.;Thakur, G.S. Chem. Soc. Rev. 2013 , 42, 569-598.

4. Rotter, M.; Tegel, M.; Johrendt, D.; Schellenberg, I.; Hermes, W.;Pottgen, R. Phys. Rev. B 2008, 78, 020503.

5. Cortes-Gil, R.; Parker, D.R.; Pitcher, M.J.; Hadermann, J.;Clarke, S.J. Chem. Mater. 2010, 22, 4304-4311.

6. Avci, S.; Allred, J.M.; Chmaissem, O.; Chung, D.Y.; Rosenkranz, S.; Schlueter, J.A.; Claus, H.; Daoud-Aladine, A.; Khalyavin, D.D.; Manuel, P.; Llobet, A.; Suchomel, M.R.; Kanatzidis, M.G.;Osborn, R. Phys. Rev. B 2013, 88, 094510.

7. Rotter, M.; Pangerl, M.; Tegel, M.;Johrendt, D. Angew. Chem. Int. Ed. 2008, 47, 7949-7952.

8. Bukowski, Z.; Weyeneth, S.; Puzniak, R.; Moll, P.; Katrych, S.; Zhigadlo, N.D.; Karpinski, J.; Keller, H.;Batlogg, B. Phys. Rev. B 2009, 79, 104521.

9. Canfield, P.C.;Bud'ko, S.L. Annu. Rev. Condens. Matter Phys. 2010, $1,27-50$

10. Jiang, S.; Xing, H.; Xuan, G.F.; Wang, C.; Ren, Z.; Feng, C.M.; Dai, J.H.; Xu, Z.A.;Cao, G.H. J. Phys.: Condens. Matter 2009, 21, 382203.

11. Rotter, M.; Tegel, M.;Johrendt, D. Phys. Rev. Lett. 2008, 101, 107006.

12. Katase, T.; Ishimaru, Y.; Tsukamoto, A.; Hiramatsu, H.; Kamiya, T.; Tanabe, K.;Hosono, H. Nat. Commun. 2011, 2, 6.

13. Weiss, J.D.; Tarantini, C.; Jiang, J.; Kametani, F.; Polyanskii, A.A.; Larbalestier, D.C.;Hellstrom, E.E. Nat. Mater. 2012, 11, 682685.

14. Ma, Y.W. Supercond. Sci. Technol. 2012, 25, 113001.

15. Sefat, A.S. Curr. Opin. Solid State Mat. Sci. 2013, 17, 59-64.

16. Avci, S.; Chmaissem, O.; Chung, D.Y.; Rosenkranz, S.; Goremychkin, E.A.; Castellan, J.P.; Todorov, I.S.; Schlueter, J.A.; Claus, H.; Daoud-Aladine, A.; Khalyavin, D.D.; Kanatzidis, M.G.;Osborn, R. Phys. Rev. B 2012, 85, 184507.

17. Ma, X.C.; Xu, F.; Atkins, T.M.; Goforth, A.M.; Neiner, D.; Navrotsky, A.;Kauzlarich, S.M. Dalton Trans. 2009, 10250-10255.

18. Yi, T.H.; Chen, S.P.; Li, S.; Yang, H.; Bux, S.; Bian, Z.X.; Katcho, N.A.; Shakouri, A.; Mingo, N.; Fleurial, J.P.; Browning, N.D.;Kauzlarich, S.M. J. Mater. Chem. 2012, 22, 24805-24813.

19. Petricek, V.; Dusek, M.; Palatinus, L. JANA2000: The Crystallographic Computing System; Institute of Physics: Praha, Czech Republic, 2000.

20. Berar, J.F.;Lelann, P. J. Appl. Crystallogr. 1991, 24, 1-5.

21. Rozsa, S.;Schuster, H.U. Z. Naturforsch., B: J. Chem. Sci. 1981, 36, 1668-1670.

22. Rudd, D.W.; Johnson, S.;Vose, D.W. J. Phys. Chem. 1962, 66, 351-\&.

23. Buxbaum, R.E.;Kinney, A.B. Ind. Eng. Chem. Res. 1996, 35, 530-537.

24. Yukawa, H.; Nambu, T.; Matsumoto, Y.; Watanabe, N.; Zhang, G.X.;Morinaga, M. Mater. Trans. 2008, 49, 2202-2207.

25. Hosono, H.;Matsuishi, S. Curr. Opin. Solid State Mat. Sci. 2013, 17, 49-58.

26. Hanna, T.; Muraba, Y.; Matsuishi, S.; Igawa, N.; Kodama, K.; Shamoto, S.;Hosono, H. Phys. Rev. B 2011, 84, 7.

27. Matsuishi, S.; Hanna, T.; Muraba, Y.; Kim, S.W.; Kim, J.E.; Takata, M.; Shamoto, S.; Smith, R.I.;Hosono, H. Phys. Rev. B 2012, 85,6 .

28. Terashima, T.; Kimata, M.; Satsukawa, H.; Harada, A.; Hazama, K.; Uji, S.; Harima, H.; Chen, G.-F.; Luo, J.-L.;Wang, N.-L. J. Phys. Soc. Jpn. 2009, 78, 063702.

29. Dong, J.K.; Zhou, S.Y.; Guan, T.Y.; Zhang, H.; Dai, Y.F.; Qiu, X.; Wang, X.F.; He, Y.; Chen, X.H.;Li, S.Y. Phys. Rev. Lett. 2010, 104, 087005.

30. Sasmal, K.; Lv, B.; Lorenz, B.; Guloy, A.M.; Chen, F.; Xue, Y.-Y.;Chu, C.-W. Phys. Rev. Lett. 2008, 101, 107007.

31. Fukazawa, H.; Yamada, Y.; Kondo, K.; Saito, T.; Kohori, Y.; Kuga, K.; Matsumoto, Y.; Nakatsuji, S.; Kito, H.; Shirage, P.M.; Kihou, K.; Takeshita, N.; Lee, C.H.; Iyo, A.;Eisaki, H. J. Phys. Soc. Jpn. 2009, 78, 083712.
32. Rotter, M.; Tegel, M.; Schellenberg, I.; Schappacher, F.M.; Pottgen, R.; Deisenhofer, J.; Gunther, A.; Schrettle, F.; Loidl, A.;Johrendt, D. New J. Phys. 2009, 11, 025014.

33. Park, J.T.; Inosov, D.S.; Niedermayer, C.; Sun, G.L.; Haug, D.; Christensen, N.B.; Dinnebier, R.; Boris, A.V.; Drew, A.J.; Schulz, L.; Shapoval, T.; Wolff, U.; Neu, V.; Yang, X.P.; Lin, C.T.; Keimer, B.;Hinkov, V. Phys. Rev. Lett. 2009, 102, 117006.

34. Song, C.-L.; Yin, Y.; Zech, M.; Williams, T.; Yee, M.M.; Chen, G.-F.; Luo, J.-L.; Wang, N.-L.; Hudson, E.W.;Hoffman, J.E. Phys. Rev. B 2013, 87, 214519.

35. Fukazawa, H.; Yamazaki, T.; Kondo, K.; Kohori, Y.; Takeshita, N.; Shirage, P.M.; Kihou, K.; Miyazawa, K.; Kito, H.; Eisaki, H.;Iyo, A. J. Phys. Soc. Jpn. 2009, 78, 033704.

36. Goko, T.; Aczel, A.A.; Baggio-Saitovitch, E.; Bud'ko, S.L.; Canfield, P.C.; Carlo, J.P.; Chen, G.F.; Dai, P.C.; Hamann, A.C.; Hu, W.Z.; Kageyama, H.; Luke, G.M.; Luo, J.L.; Nachumi, B.; Ni, N.; Reznik, D.; Sanchez-Candela, D.R.; Savici, A.T.; Sikes, K.J.; Wang, N.L.; Wiebe, C.R.; Williams, T.J.; Yamamoto, T.; Yu, W.;Uemura, Y.J. Phys. Rev. B 2009, 80, 6.

37. Yeoh, W.K.; Gault, B.; Cui, X.Y.; Zhu, C.; Moody, M.P.; Li, L.; Zheng, R.K.; Li, W.X.; Wang, X.L.; Dou, S.X.; Sun, G.L.; Lin, C.T.;Ringer, S.P. Phys. Rev. Lett. 2011, 106, 247002. 
1

2

3

4

5

6

7

8

9

10

11

12

13

14

15

16

17

18

19

20

21

22

23

24

25

26

27

28

29

30

31

32

33

34

35

36

37

38

39

40

41

42

43

44

45

46

47

48

49

50

51

52

53

54

55

56

57

58

59

60

Table of Contents

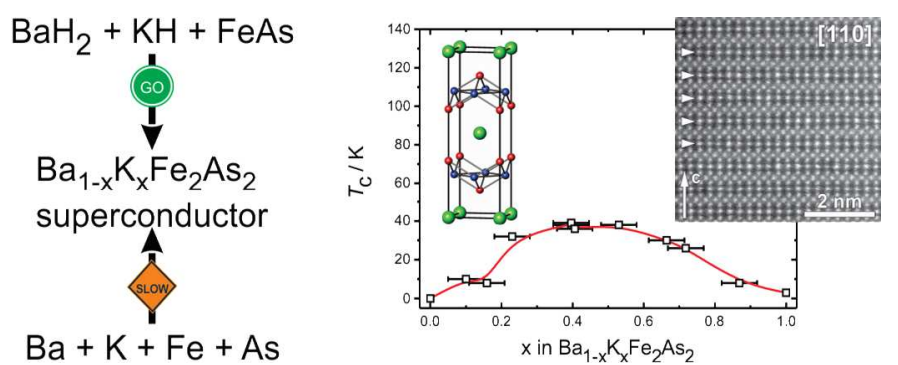



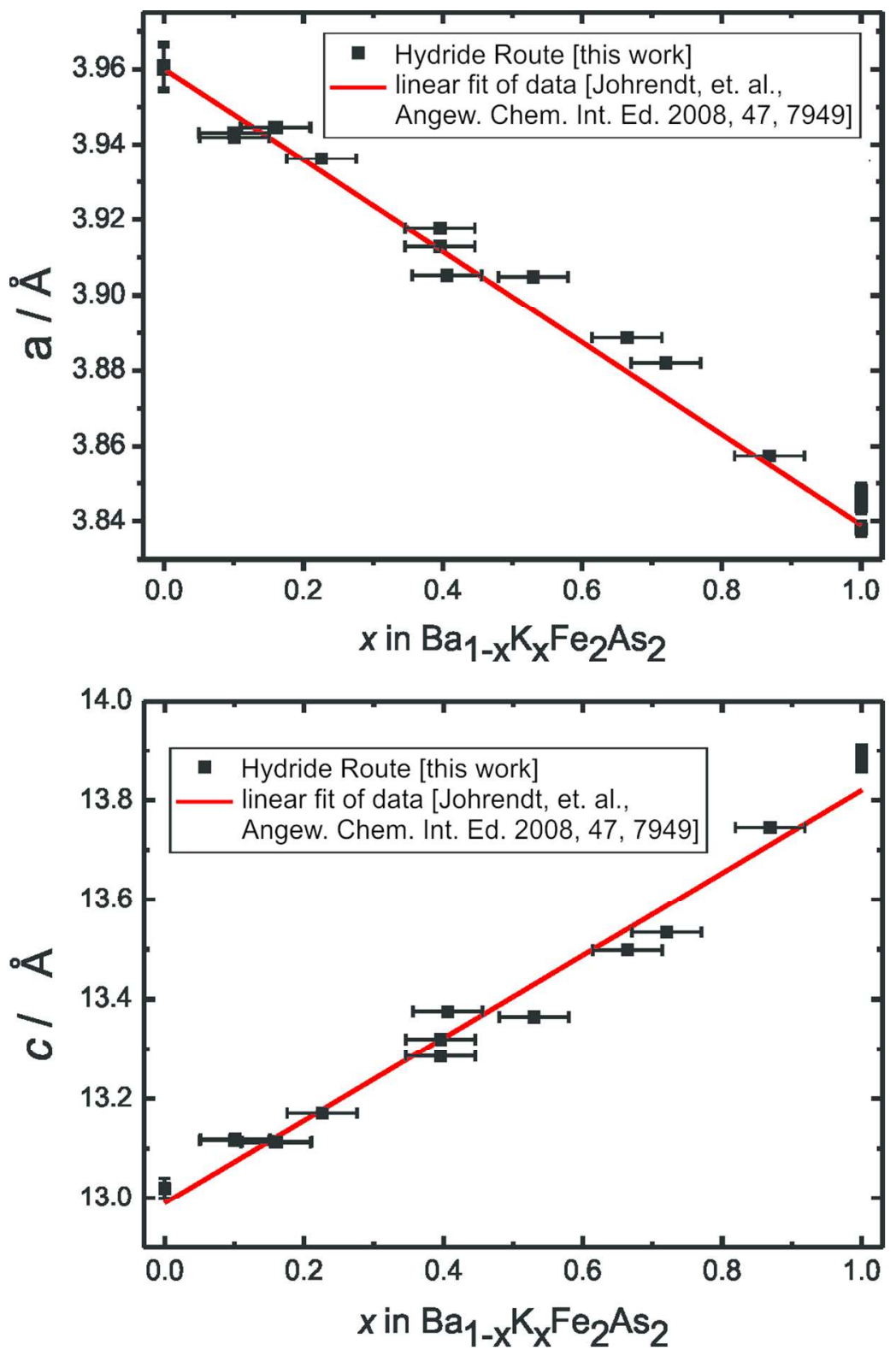

Figure 3. Variation of unit cell parameters with potassium content, $\mathrm{x}$, in $\mathrm{Ba}_{1-\mathrm{x}} \mathrm{K}_{\mathrm{x}} \mathrm{Fe}_{2} \mathrm{As}_{2}$. For comparison linear fit of data by Johrendt et al.7 is plotted as red line. Error bars for the unit cell parameters are smaller than the symbols used for the experimental data. $92 \times 141 \mathrm{~mm}(300 \times 300$ DPI $)$ 
Figure 6. HAADF-STEM images for the $\mathrm{Ba}_{0.5} \mathrm{~K}_{0.5} \mathrm{Fe}_{2} \mathrm{As}_{2}$ sample taken along [001], [100] and [110] zone axes. Arrowheads indicate the $\mathrm{Ba} / \mathrm{K}$ layers in the structure. The structure looks homogeneous along [001] and [100] directions, while along the [110] direction some $\mathrm{Ba} / \mathrm{K}$ columns appear noticeably brighter or weaker than the others, indicating slightly inhomogeneous $\mathrm{Ba} / \mathrm{K}$ distribution.

$249 \times 754 \mathrm{~mm}(300 \times 300 \mathrm{DPI})$ 

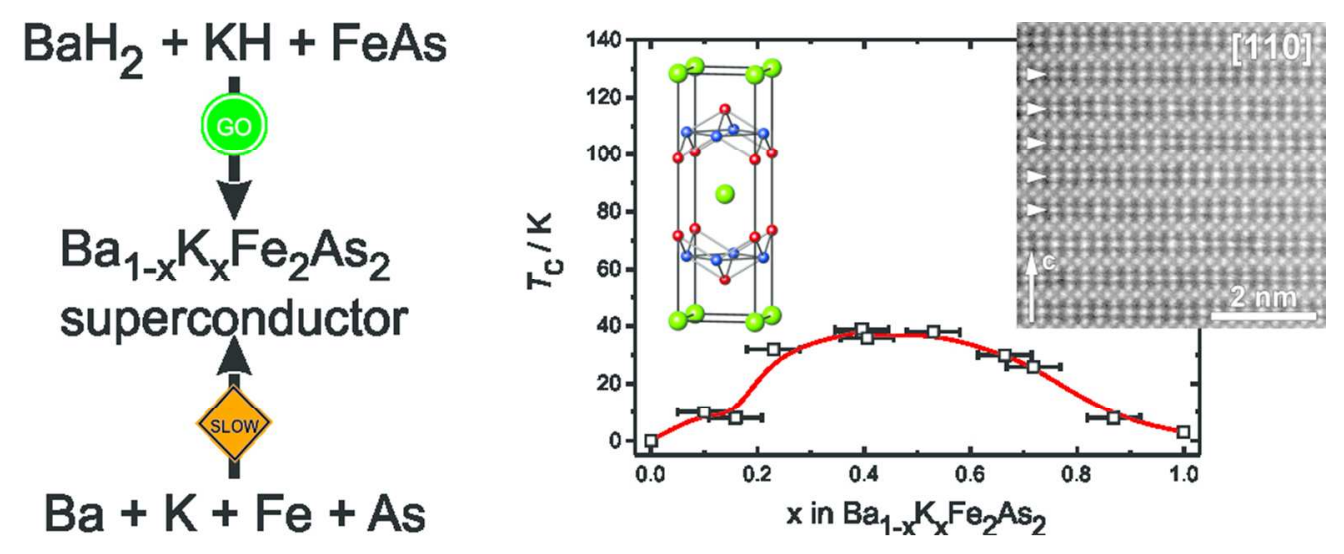

$88 \times 34 \mathrm{~mm}(300 \times 300$ DPI $)$ 


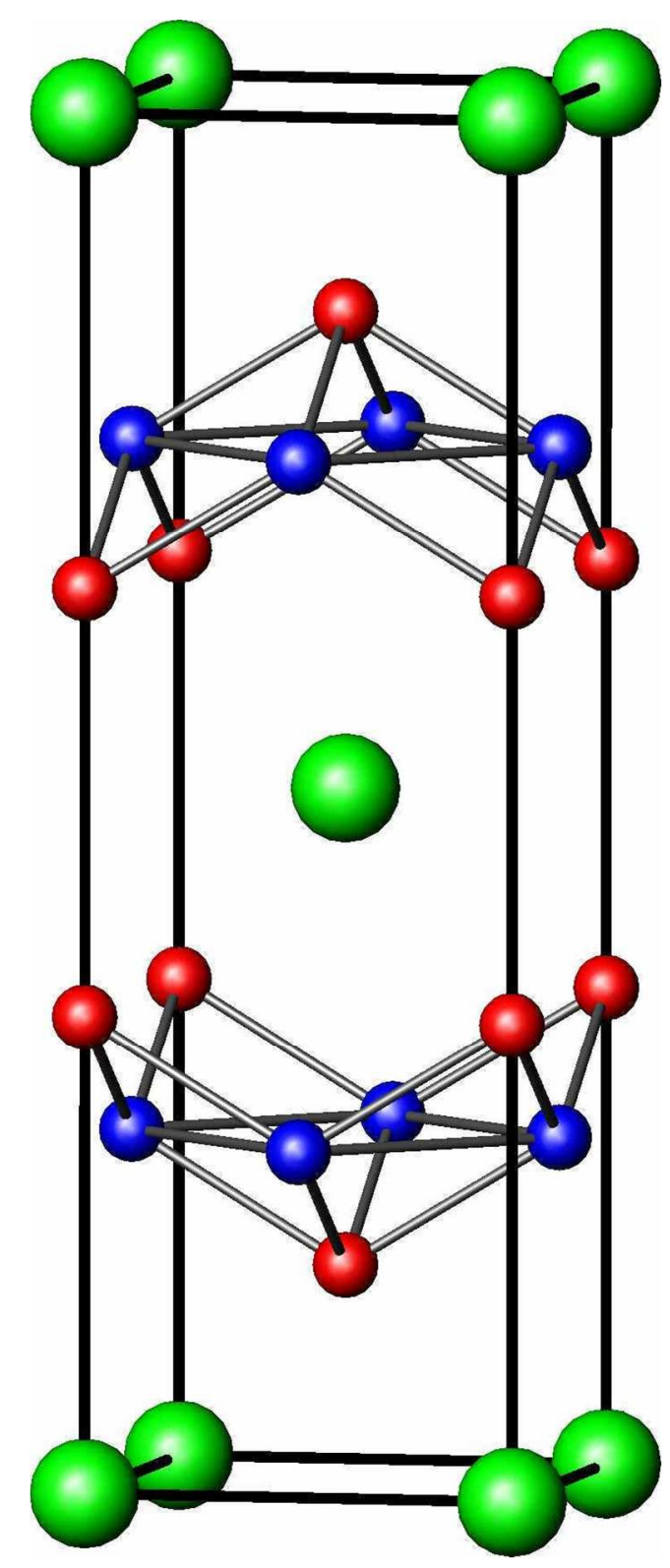

Figure 1. Crystal structure of BaFe2As2. Ba: green, Fe: blue, As: red. $60 \times 146 \mathrm{~mm}(300 \times 300$ DPI $)$ 

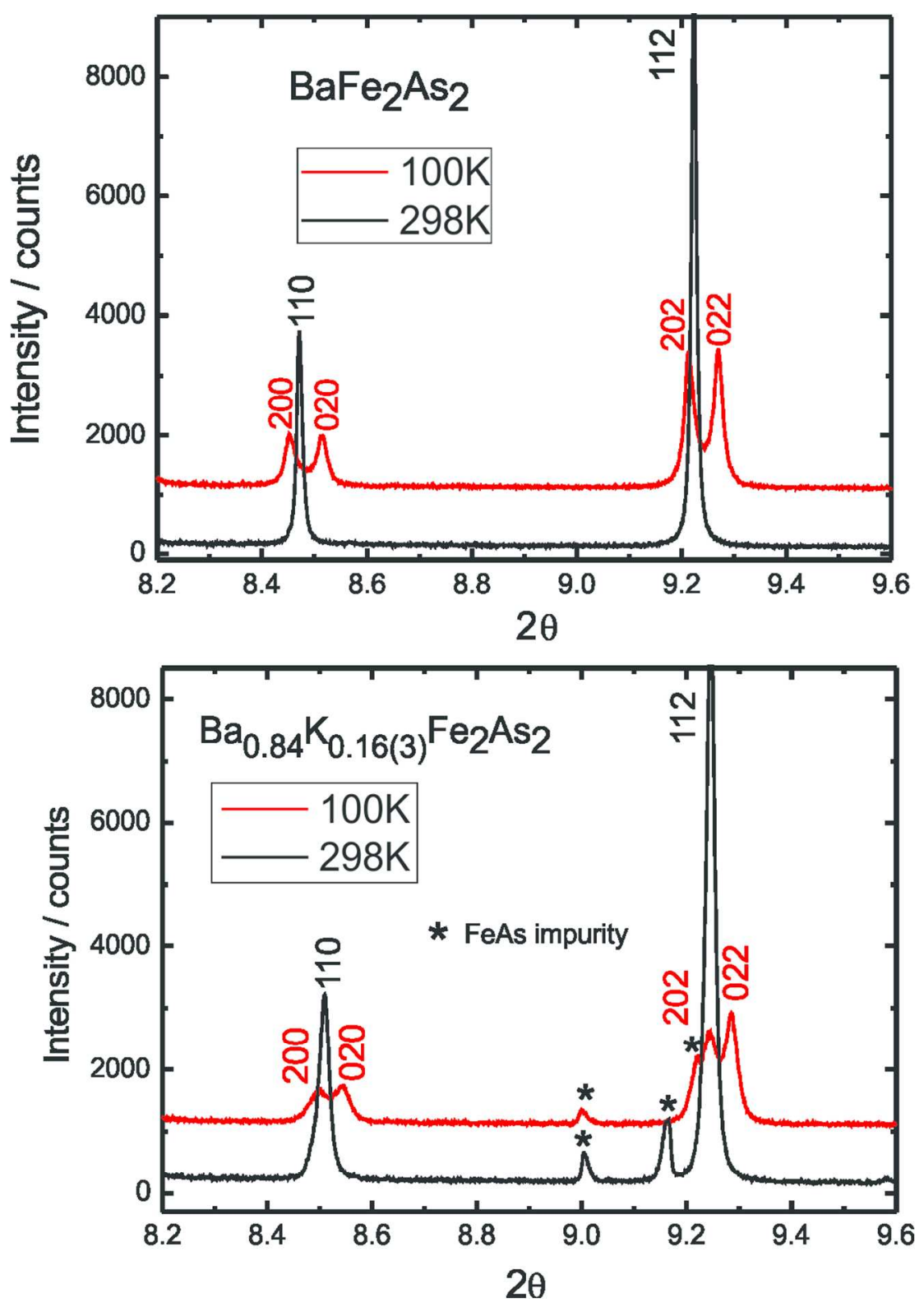

Figure 2. Splitting of (110) and (112) reflections for BaFe2As2 (top) and Ba0.84K0.16(3)Fe2As2 (bottom) upon cooling from room temperature( black) to $100 \mathrm{~K}$ (red). $96 \times 136 \mathrm{~mm}(300 \times 300 \mathrm{DPI})$ 

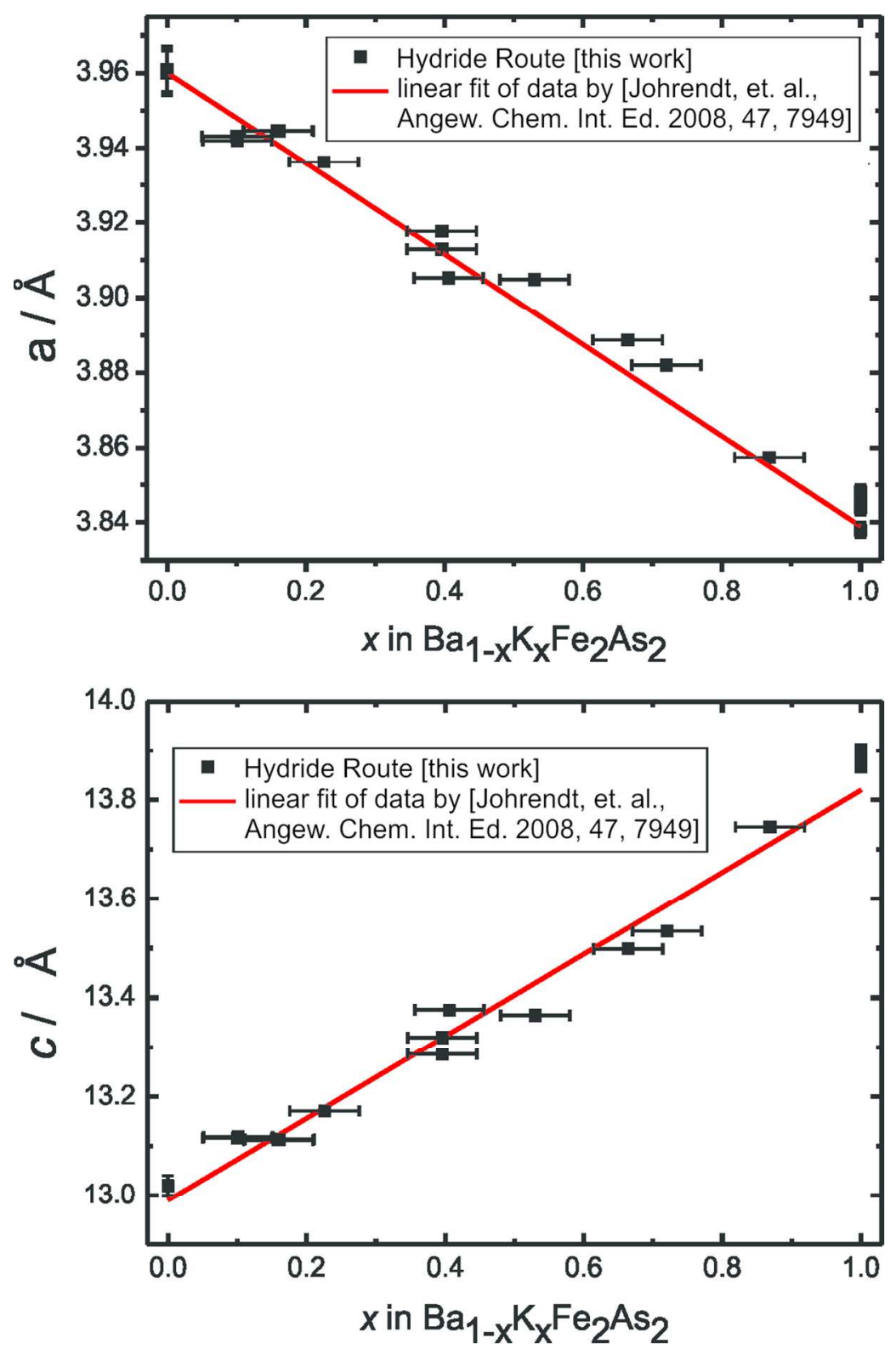

Figure 3. Variation of unit cell parameters with potassium content, $x$, in Ba1-xKxFe2As2. For comparison linear fit of data by Johrendt et al.7 is plotted as red line. Error bars for the unit cell parameters are smaller than the symbols used for the experimental data. $92 \times 141 \mathrm{~mm}(300 \times 300 \mathrm{DPI})$ 


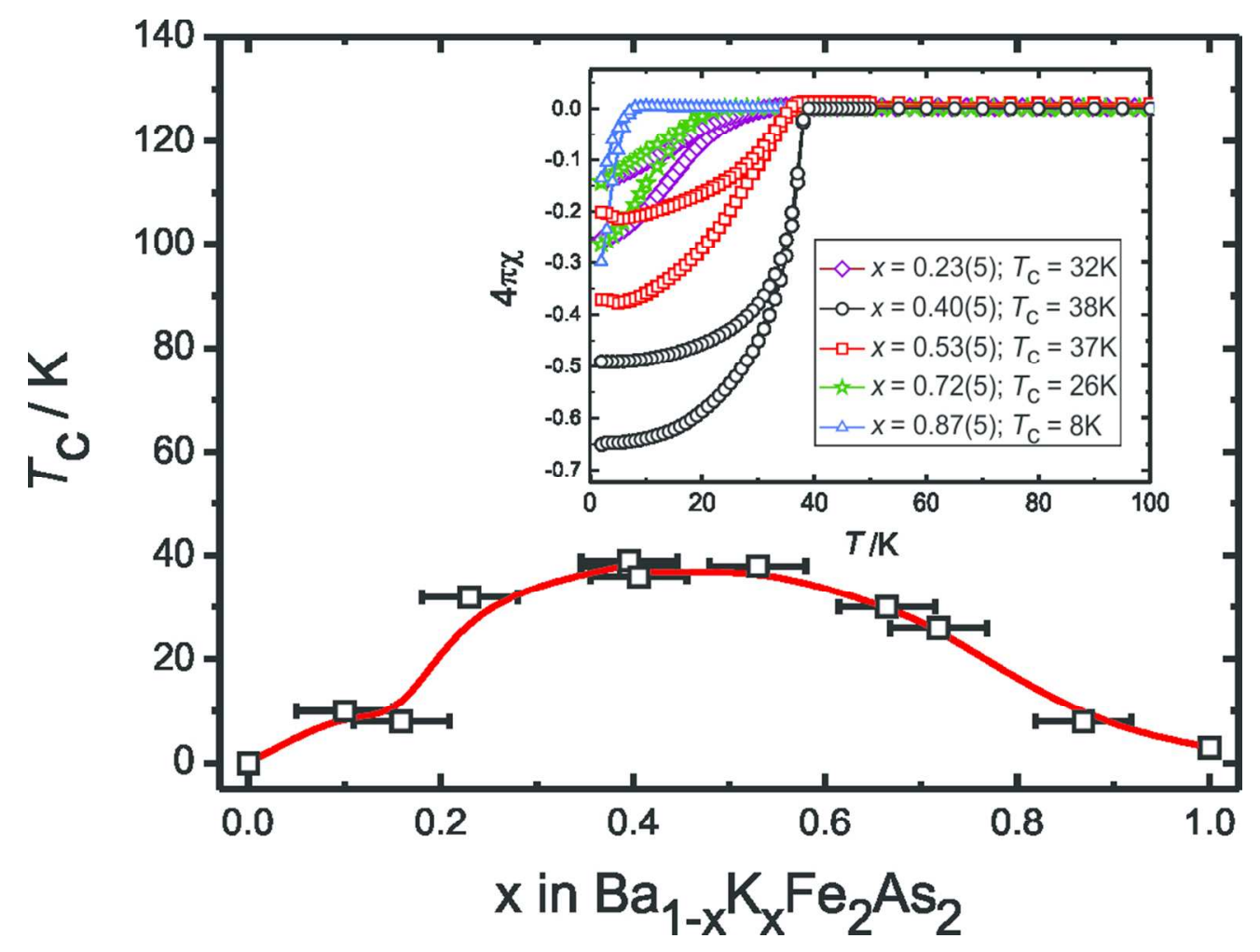

Figure 4. Compositional dependence of superconducting transition temperature, Tc, upon potassium content, $\mathrm{x}$, in $\mathrm{Ba} 1-\mathrm{xKxFe2As2}$. Insert: temperature dependence of magnetization measured in the applied field of 10 Oe. $93 \times 70 \mathrm{~mm}(300 \times 300 \mathrm{DPI})$ 

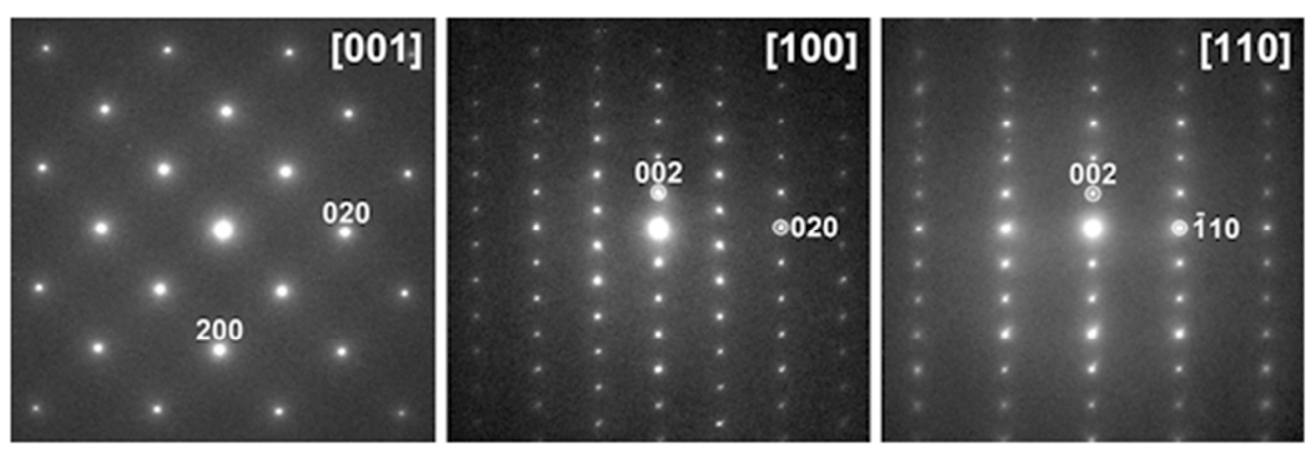

Figure 5. ED patterns along the main crystallographic axes of the Ba0.5K0.5Fe2As2 structure. $49 \times 16 \mathrm{~mm}(300 \times 300$ DPI) 


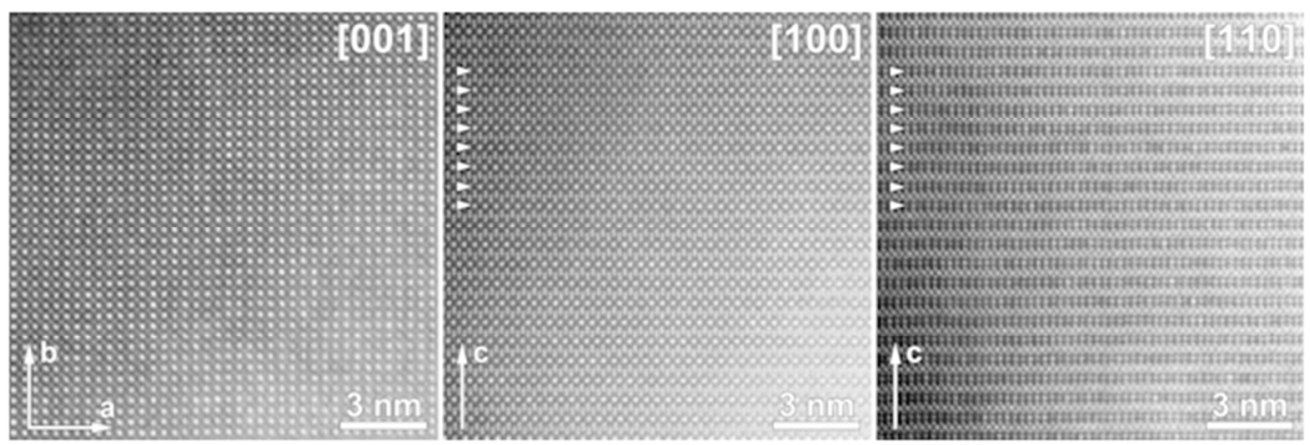

Figure 6. HAADF-STEM images for the Ba0.5K0.5Fe2As2 sample taken along [001], [100] and [110] zone axes. Arrowheads indicate the $\mathrm{Ba} / \mathrm{K}$ layers in the structure. The structure looks homogeneous along [001] and [100] directions, while along the [110] direction some $\mathrm{Ba} / \mathrm{K}$ columns appear noticeably brighter or weaker than the others, indicating slightly inhomogeneous $\mathrm{Ba} / \mathrm{K}$ distribution.

$54 \times 18 \mathrm{~mm}(300 \times 300 \mathrm{DPI})$ 
Figure 7. Enlarged [110] HAADF-STEM image for the Ba0.5K0.5Fe2As2 sample with marked Ba/K layers 1 11 . The intensity profiles were measured from the parts marked with brackets in layers 4 and 5 . Alternation of the Ba-enriched and Ba-depleted columns is marked with black and white arrows, respectively. No specific ordering occurs for the rest of the layers. $26 \times 21 \mathrm{~mm}(300 \times 300 \mathrm{DPI})$ 
Figure 8. Scheme of the $\mathrm{Ba} / \mathrm{K}$ ordering in $\mathrm{Ba0} .5 \mathrm{~K} 0.5 \mathrm{Fe} 2 \mathrm{As} 2$ viewed along the [001] direction. The unit cells of the basic $a \times a \times c$ structure and of the $\sqrt{2} a \times \sqrt{2} a \times c$ superstructure are outlined. Ba: green, $\mathrm{K}$ : orange, Fe: blue, As: red. $20 \times 19 \mathrm{~mm}(300 \times 300 \mathrm{DPI})$ 


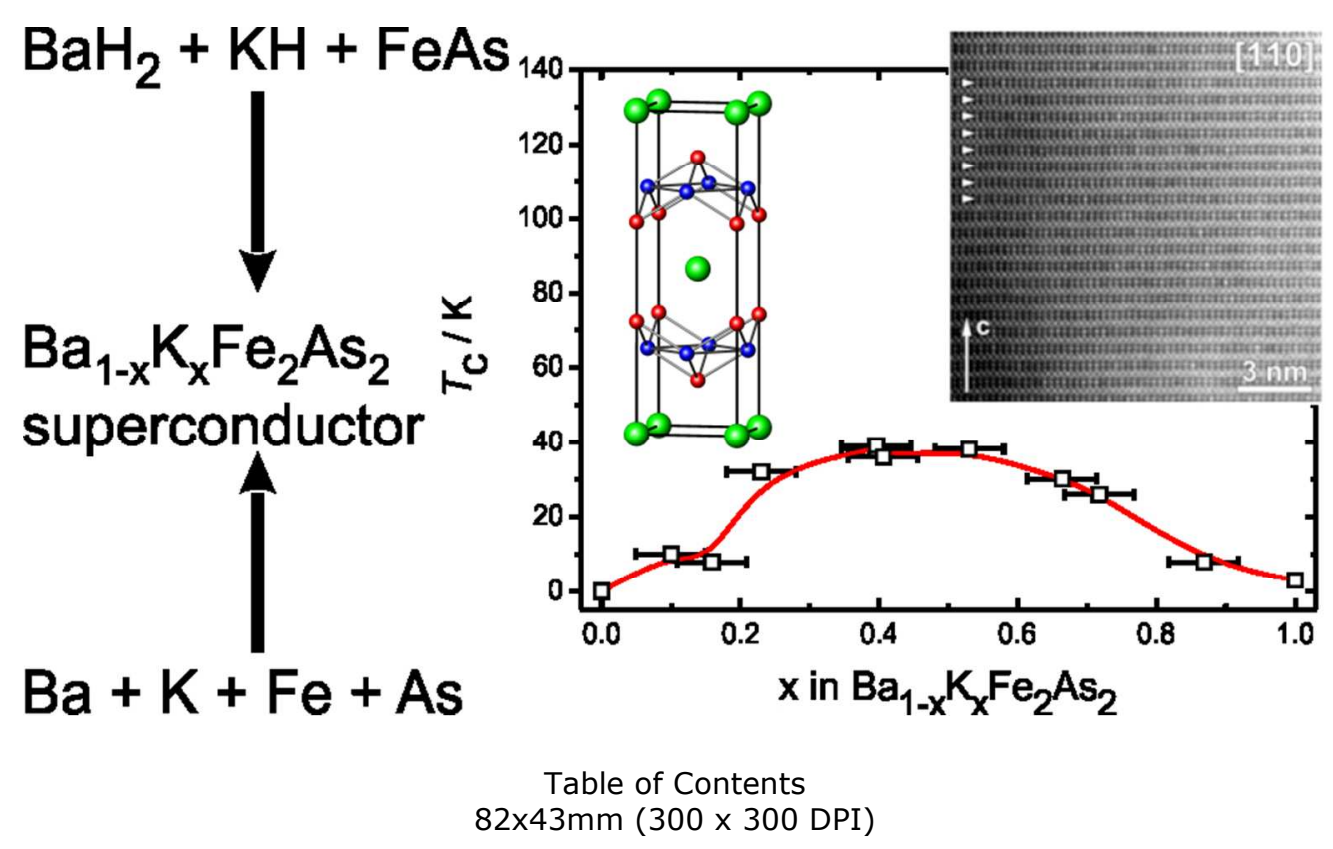

